berlei, T. and Johnson, T. and White, R and Roffeis, C. and Stüwe, K. 2014. Thermobarometric constraints on pressure variations across the Plattengneiss shear zone of the Eastern Alps: Implications for exhumation models during Eoalpine subduction. Journal of Metamorphic Geology. 32 (2): pp. 227-244.

\title{
Thermobarometric constraints on pressure variations across the Plattengneiss shear zone of the Eastern Alps: Implications for exhumation models during Eoalpine subduction
}

\begin{tabular}{|r|l|}
\hline Journal: & Journal of Metamorphic Geology \\
\hline Manuscript ID: & JMG-13-0068.R1 \\
\hline Manuscript Type: & Original Article \\
\hline Complete List of Authors: & $\begin{array}{l}\text { Eberlei, Tobias; Johannes Gutenberg University Mainz, Institute of } \\
\text { Geoscience } \\
\text { Johnson, Tim; Johannes Gutenberg University Mainz, Institute of } \\
\text { Geoscience; } \\
\text { White, Richard; Johannes Gutenberg University Mainz, Institute of } \\
\text { Geoscience; The University of Mainz, Institute of Geoscience } \\
\text { Roffeis, Cornelius; Institut für Erdwissenschaften, Universität Graz } \\
\text { Stüwe, Kurt; Institut für Erdwissenschaften, Universität Graz }\end{array}$ \\
\hline Keywords: & $\begin{array}{l}\text { exhumation, Koralpe, mineral equilibria modelling, relative } \\
\text { thermobarometry, slab extraction }\end{array}$ \\
\hline \multicolumn{2}{|c}{} \\
\hline
\end{tabular}




\section{Thermobarometric constraints on pressure variations across the Plattengneiss shear zone of the Eastern Alps: Implications for exhumation models during Eoalpine subduction}

T. Eberlei, ${ }^{1 \dagger}$ T.E. Johnson, ${ }^{1 *}$ R.W. White, ${ }^{1}$ C. Roffeis, ${ }^{2}$ and K. Stüwe ${ }^{2}$

${ }^{1}$ Earth System Science Research Centre, Institute for Geosciences, University of Mainz,

Becherweg 21, D-55099, Mainz, Germany

${ }^{2}$ Department of Earth Science, University of Graz, Universitätsplatz 2, A-8010 Graz, Austria

*Corresponding author (tjohnson@uni-mainz.de)

${ }^{\dagger}$ Current address: Department for Lithospheric Research, University of Vienna, Althanstraße 14,

1090, Vienna, Austria 


\begin{abstract}
Forward and inverse mineral equilibria modelling of metapelitic rocks in the hangingwall and footwall of the Plattengneiss, a major shear zone in the Eastern Alps, are used to constrain their tectonometamorphic evolution and assess models for their exhumation. Forward (pseudosection) modelling of two metapelitic rocks suggests a steep clockwise $P-T$ path with a near-isothermal decompression segment from a pressure peak at around $18-19 \mathrm{kbar}$ and $670^{\circ} \mathrm{C}$ to the metamorphic peak at $680-720^{\circ} \mathrm{C}$ and $11-13 \mathrm{kbar}$. A subsequent decrease to $600-645^{\circ} \mathrm{C}$ and $8-9 \mathrm{kbar}$ is inferred from the late growth of staurolite in some samples. Conventional thermobarometric calculations (inverse modelling) on 18 samples with the inferred peak assemblage garnet + plagioclase + muscovite + biotite + quartz + rutile \pm ilmenite \pm kyanite are associated with large $2 \sigma$ uncertainties, and absolute pressures calculated for all samples are statistically indistinguishable. However, calculations constraining relative pressure differences $(\Delta P)$ between samples sharing a common mineral assemblage are associated with much smaller uncertainties and yield pressure differences that are statistically meaningful. Although the overall pattern is complicated, the results suggest a pressure gradient of up to $3 \mathrm{kbar}$ across the shear zone that is consistent with volume loss and a model of exhumation related to slab extraction for the Plattengneiss shear zone.
\end{abstract}

Key words: exhumation, Koralpe, mineral equilibria modelling, relative thermobarometry, slab extraction 


\section{INTRODUCTION}

Eclogite facies rocks are a common feature of many collisional orogens such as the Alps. The occurrence of such rocks generally implies subduction and subsequent return of crustal material to the surface, although the precise mechanisms by which rocks are exhumed from depths commonly exceeding $50 \mathrm{~km}$ remain unclear. Several models have been proposed to explain exhumation of eclogite facies rocks in the Alps including erosion, buoyancy-driven wedge extrusion in a subduction channel (Chemenda et al., 1995), crustal extension and erosion (Cartwright \& Barnicoat, 2002), slab break-off (von Blanckenburg \& Davies, 1995), exhumation as a core complex (Kurz et al., 2002) and, most recently, slab extraction (Froitzheim et al., 2003, 2006).

Accurately constraining the pressure-temperature $(P-T)$ history of rocks is critical in testing the validity of models to explain their exhumation. However, conventional thermobarometric calculations based on the chemical composition of minerals assumed to have attained equilibrium are typically associated with $2 \sigma$ uncertainties of $\pm 1.5 \mathrm{kbar}$ and $\pm 50^{\circ} \mathrm{C}$ and commonly more (Kohn \& Spear, 1991; Spear, 1995; Worley \& Powell, 2000; Powell \& Holland, 2008). Even where co-existing solid solution minerals are apparently well-equilibrated (i.e. lack compositional zoning), additional errors derive from uncertainties on analysed mineral compositions, end member thermodynamic data and activity-composition relations (Hodges \& McKenna, 1987; Worley \& Powell, 2000; Powell \& Holland, 2008). However, many geological problems do not require absolute pressure determinations and relative differences in the $P-T$ conditions recorded by rocks from critical locations may be sufficient to solve the tectonic problem in question (Fraser 
et al., 2000; Worley \& Powell, 2000). In a relative $P-T$ approach, many of the uncertainties associated with absolute thermobarometric calculations will cancel, potentially enabling the investigation of geodynamic problems where small pressure variations are critical.

One such problem concerns the tectonic significance of the Plattengneiss, a major flat-lying Eoalpine shear zone in the Koralpe region of the Eastern Alps (Fig. 1), the type locality for eclogite (Hauy, 1822). It has been suggested that this mylonitic shear zone facilitated exhumation of the eclogite bodies of the region (e.g. Kurz et al., 2002). However, more recent geometrical studies of the Plattengneiss shear zone have shown that eclogite bodies occur both above and below the shear zone, questioning the role of the shear zone as the mechanisms of exhumation (Putz et al., 2006).

More recent studies have suggested that the Plattengneiss shear zone may form a suture zone related to Eoalpine subduction (Stüwe \& Schuster, 2010), similar in geometry to an extraction fault (Froitzheim et al., 2006). The shear zone may have formed as a suture zone during downward extraction of material in the hanging wall of the subducted Austroalpine crust (Froitzheim et al., 2003; Stüwe \& Schuster, 2010). Such a model implies significant volume loss from within the shear zone and thus should be associated with a significant difference in the metamorphic pressures recorded by rocks on either side of the shear zone.

Here we constrain relative pressure differences across the Plattengneiss shear zone using thermodynamic calculations and an innovative relative $P-T$ approach in order to constrain volume loss within the Plattengneiss shear zone. Our results are interpreted in terms of the role of the shear zone in the Eoalpine tectonic evolution. 


\section{GEOLOGICAL SETTING}

The crystalline Koralpe complex is part of the Austroalpine nappe stack of the European Eastern Alps (Fig. 1a). It is bordered by the Gleinalpe dome to the north, is juxtaposed against the Saualpe basement block in the west, dips eastwards beneath the Pannonian Basin to the east and is bounded by the south-dipping Plankogel detachment to the south (Fig. 1b). Together with the adjacent Saualpe, the Koralpe represents the largest Alpine region that records an intense Cretaceous amphibolite to eclogite facies metamorphic event, commonly referred to as the Eoalpine event (e.g. Frank, 1987; Tenczer et al., 2006; Frey et al., 1999; Oberhänsli \& Goffé, 2004). The Eoalpine event is characterized by the occurrence of eclogite facies metamorphism within a zone of the Austroalpine basement that can be traced from the Koralpe region as a belt extending as far as the Texel group in the southern Ötztal basement in the west (Habler et al., 2006). Outside of this belt the metamorphic grade decreases rapidly northwards to greenschist or subgreenschist facies conditions (Thöni, 1983; Tenczer and Stüwe, 2003; Faryad \& Hoinkes, 2003).

The Koralpe basement comprises a complex series of metapelitic micaschists with intercalations of eclogite, garnetiferous pegmatite, calcsilicate, marble, amphibolite and metagabbro. The eclogites occur as bodies ranging from a few metres to more than 100 metres across. The Koralpe experienced two metamorphic events. An earlier (late Permian to early Triassic) event records peak conditions of $600-650^{\circ} \mathrm{C}$ and $3.8-6.5 \mathrm{kbar}$ 
(Habler \& Thöni, 2001; Tenczer et al., 2006) and was associated with the intrusion of pegmatite at around $250 \mathrm{Ma}$ (Habler \& Thöni, 2001). Later Eoalpine metamorphism is dated at c.90-100 Ma (Thöni \& Jagoutz, 1993). Conditions of around $700^{\circ} \mathrm{C}$ and $14 \mathrm{kbar}$ are recorded by peak assemblages in metapelitic rocks (e.g. Gregurek et al., 1997; Stüwe \& Powell, 1995; Tenczer et al., 2006). The eclogites were formed during this Eoalpine event from gabbroic precursors (dated to have intruded at $257 \pm 21 \mathrm{Ma}$; Miller \& Thöni, 1997). Assemblages within eclogites record pressures of around 18-19 kbar (e.g. Bruand et al., 2009), consistent with garnet core compositions in metapelitic rocks (Thöni \& Miller, 1996).

Deformation associated with the Eoalpine event affected all basement lithologies to varying extents. A major Eoalpine structural feature of the Koralpe basement is the mylonitic Plattengneiss shear zone, a broadly flat-lying structure that lies on the eastern topographic dip slope of the Koralpe range (Fig. 1b,c). The Plattengneiss is between 250 and 600 metres thick and about $500 \mathrm{~km}^{2}$ in areal extent (Putz et al., 2006), forming one of the largest shear zones in the Eastern Alps. It is characterized by a prominent N-S trending mineral stretching lineation and contains boudinaged lenses and pods of eclogite that occur above, below and within the shear zone. Syndeformational Eoalpine parageneses indicate that deformation also occurred in the Cretaceous (Stüwe, 1998; Kurz et al., 1999). Importantly, the shear zone is warped by a later deformation event into large open folds with wavelengths of many kilometres and amplitudes of a few hundred metres, providing access to exposures above, below and within the shear zone (Fig. 1c,d). The tectonic significance of the Plattengneiss shear zone remains unclear. Thöni \& Jagoutz (1993) and Stüwe and Schuster (2010) inferred that the structure relates to 
orogen-scale (and possibly intracontinental) subduction during the Cretaceous. However, shear sense indicators within the Plattengneiss shear zone are generally unclear. Kurz et al. (2002) attempted to determine the kinematics of the shear zone using quartz fabric analysis. Although recrystallisation postdating high temperature $\left(\sim 700{ }^{\circ} \mathrm{C}\right)$ deformation yielded equivocal results, Kurz et al. (2002) interpreted their data in terms of top-to-thenorth motion in the north of the shear zone and top-to-the-south in the south of the shear zone (light grey arrows on Fig. 1d). From this they suggested that the Plattengneiss shear zone may be a detachment fault responsible for exhuming the eclogites. An alternative interpretation of their data is that the shear sense reverses not in a north-south direction (i.e. laterally), but across the shear zone (i.e. vertically from top to bottom), and that the shear zone forms a suture zone of a southward extruding channel (see inset on Fig. 1d). Hatley et al., (2009) and Hatley (2010) attempted to document such a reversal of shear sense across the Plattengneiss by EBSD measurements of samples from specific locations within the shear zone. However, akin to the problems experienced by Kurz et al. (2002), late dynamic recrystallisation of quartz led to equivocal results. However, an implication of the channel flow model is that significant volume loss may have occurred from within the shear zone. This will be investigated here using detailed relative $P-T$ determinations.

\section{FIELD RELATIONS AND PETROGRAPHY}

The Koralpe region is characterized by pronounced relief, ranging from 350 metres near Deutschlandsberg to 2170 metres at the summit of Grosser Speikkogel. The most 
characteristic lithological feature of the complex is the mylonitic Plattengneiss with its strong foliation, N-S orientated mineral stretching lineation (Fig. 2a) and boudinage of more competent layers within volumetrically dominant metapelitic gneisses (Fig. 2b). Outside the shear zone, metapelitic rocks (dominantly garnet-bearing micaschists) have typical amphibolite facies assemblages in which kyanite pseudomorphs replacing andalusite are common (Figs 2c,d). Minor rock types include garnet-bearing calcsilicates (Fig. 2e), garnetiferous pegmatites, and partly eclogitized gabbros (Fig. 2f), the latter commonly exhibiting a retrograde amphibolite facies overprint. Outcrop is generally limited with good exposures concentrated in the central and southern portion of the Koralpe. No clear evidence for partial melting of the metapelitic basement rocks during Eoalpine metamorphism has been found.

The Plattengneiss is assumed to be a single mylonitic sheet rather than a complex set of smaller discrete shear zones (Putz et al., 2006) and, for the purpose of this study, the investigated rocks are divided simply into a hangingwall unit and a footwall unit. Samples of metapelitic rocks from nine locations in the hangingwall and nine localities in the footwall were collected for detailed study (Table 1). Localities were selected based on the modelled three-dimensional distribution of the various lithological units (Putz et al., 2006). In total, some 3 kilometres of vertical cross section across the shear zone could be sampled. Metapelitic samples from both the hangingwall and footwall are similar with only minor chemical, microstructural and paragenetic differences. All contain the inferred peak assemblage garnet + plagioclase + biotite + muscovite + quartz + rutile \pm ilmenite \pm kyanite. Additional minor phases include paragonite, staurolite, clinozoisite, apatite, tourmaline and/or zircon. 


\section{Hangingwall samples}

Samples from the hangingwall are predominantly medium- to coarse-grained metapelitic schists containing abundant garnet porphyroblasts up to $5 \mathrm{~mm}$ across. Some garnets have inclusion-rich cores and inclusion-poor rims (Fig. 3a), whereas others contain only a few inclusions (Figs 3b,c). Inclusions in garnet include muscovite, paragonite, staurolite, rutile, biotite, quartz and plagioclase. Rarely, garnet porphyroblasts within mica-rich domains have inclusion-rich cores and inclusion-poor rims and are surrounded by numerous fractured sub-mm sized garnets (Fig. 3d). Staurolite occurs as sub-mm sized poikiloblasts spatially associated with porphyroblasts of garnet and kyanite (Fig. 3e). The matrix is commonly dominated by white mica and subordinate biotite, both of which define a weak preferred orientation (Fig. 3f). In more calcareous samples, plagioclase forms millimetre-sized porphyroblasts and is associated with small clinozoisite grains ( $\sim 0.1 \mathrm{~mm}$ in size) that overgrow the micaceous matrix (Fig. 3f). However, in most samples, plagioclase occurs as a matrix mineral together with quartz. Rutile occurs both as inclusions in garnet or as small matrix grains $(<0.5 \mathrm{~mm})$ that are surrounded by a corona of ilmenite (Figs 3b,c). Matrix rutile is commonly spatially associated with white mica, biotite and acicular ilmenite. Minor phases include kyanite at the margins of garnet (Fig. 3c), chlorite adjacent to staurolite, biotite, tourmaline and, in calcareous samples, apatite and clinozoisite. 


\section{Footwall samples}

Samples from the footwall are similar to those in the hangingwall but commonly are finer-grained, more highly deformed and contain a higher proportion of quartz and feldspar (Fig. 4b). Biotite is generally rare and restricted to pressure shadows around, and fractures within, garnet and garnet aggregates. However, several samples contain millimetre-sized biotite grains that are overgrown by small inclusion-free garnets (Fig. 4a). Kyanite aggregates within the matrix have been interpreted as pseudomorphs after andalusite and/or sillimanite (Habler \& Thöni, 2001). Some kyanite aggregates are several centimetres across and, in rare cases, are overgrown by garnet (Fig. 4e). Finegrained muscovite defines a continuous foliation within the matrix and also occurs replacing kyanite pseudomorphs and recrystallized feldspar aggregates (Figs 4c,e). In addition, some samples contain small porphyroblasts of muscovite $(<1 \mathrm{~mm})$ that are replaced at their margins by biotite and overgrown by small $(<1 \mathrm{~mm})$ euhedral garnets (Fig. 4d). Minor and accessory phases include rutile, which occurs as small grains $(<0.1$ $\mathrm{mm}$ ) within the matrix, along with chlorite and paragonite. Ilmenite is absent from most footwall samples (Fig. 4f).

\section{MINERAL CHEMISTRY}


All analyses were undertaken at the Institute for Geoscience, University of Mainz using a JEOL JXA 8900 RL electron probe microanalyser (EPMA) using an acceleration voltage of $15 \mathrm{kV}$, a beam current of $12 \mathrm{nA}$ and a beam diameter of $2 \mu \mathrm{m}$ for all phases except feldspars $(5 \mu \mathrm{m})$. Both synthetic and natural standards were used. Mineral formulae were recalculated assuming all $\mathrm{Fe}$ as $\mathrm{Fe}^{2+}$ in all phases except plagioclase and clinozoisite (which assume all $\mathrm{Fe}$ as $\mathrm{Fe}^{3+}$ ). Representative mineral analyses are given in Table 2 (hangingwall samples) and Table 3 (footwall samples).

\section{Hangingwall samples}

Garnet porphyroblasts are typically almandine-rich with $X_{\mathrm{alm}}[=\operatorname{molar} \mathrm{Fe} /(\mathrm{Fe}+\mathrm{Mg}+\mathrm{Ca}$ $+\mathrm{Mn})]=0.65-0.70$ and $X_{\mathrm{gr}}[=\mathrm{Ca} /(\mathrm{Fe}+\mathrm{Mg}+\mathrm{Ca}+\mathrm{Mn})]=0.06-0.16$. Pyrope contents are variable but typically $X_{\mathrm{py}}[=\mathrm{Mg} /(\mathrm{Fe}+\mathrm{Mg}+\mathrm{Ca}+\mathrm{Mn})]>0.19$. Large garnet grains commonly exhibit growth zoning, with weakly increasing $\mathrm{Mg}$ - and decreasing $\mathrm{Mn}$ contents from core to $\operatorname{rim}(\mathrm{Mn}=0.09-0.01$ cations per formula unit [= c.p.f.u.] based on 12 oxygens) (Fig. 5a). Within the outermost rims of large garnet porphyroblasts, $X_{\text {py }}$ decreases and $X_{\text {alm }}$ and $X_{\text {spss }}$ increase towards the rim (Fig. 5a), consistent with limited retrograde diffusional resetting. Exceptions to these typical patterns exist. Small, unzoned garnets in the Ca-rich sample T29 from the Schwanberger Gneis unit (Fig. 3f) are richer in $X_{\mathrm{gr}}(0.26-0.40), X_{\mathrm{alm}}(0.80-0.87)$ and $\mathrm{Mn}(0.09-0.12$ c.p.f.u. $)$.

Biotite compositions show some variability, although there is no clear systematic variation with respect to textural setting. In most analyses $X_{\mathrm{Fe}}\left[=\right.$ molar $\left.\mathrm{Fe}^{2+} /\left(\mathrm{Fe}^{2+}+\mathrm{Mg}\right)\right]$ 
varies between 0.35 and 0.50 . Titanium-contents are variable with most grains having $<0.15$ c.p.f.u. Ti, (based on 11 oxygens). Ca-contents are low $(<0.08$ wt.\%). Biotite typically has around 2.8 c.p.f.u. Si and $1.55-1.60$ c.p.f.u. Al, in which calculated $X_{\mathrm{Al} \text { M1 }}$ $\left(=\mathrm{Al}{ }^{\mathrm{VI}}\right.$ c.p.f.u. $)$ ranges between 0.3 and 0.5 . White mica is almost exclusively phengitic muscovite, containing $3.09-3.28$ c.p.f.u. $(11 \mathrm{O}) \mathrm{Si}$ and with $X_{\mathrm{Na}}[=\mathrm{Na} /(\mathrm{Na}+\mathrm{K})]$ typically between 0.15 and 0.23 . Ca-contents are low $(<0.03$ wt.\%). A mm-sized growth-zoned garnet in sample T4 (Fig. 3a) contains abundant paragonite inclusions with $0.3-0.8$ wt.\% $\mathrm{CaO}, 3.00$ c.p.f.u. Si and 6-7 wt.\% $\mathrm{Na}_{2} \mathrm{O}\left(X_{\mathrm{Na}} 0.88-0.92\right)$.

Small anhedral plagioclase grains $(<0.5 \mathrm{~mm})$ are weakly zoned with $X_{\mathrm{ab}}[=$ molar $\mathrm{Na} /(\mathrm{Na}+\mathrm{Ca}+\mathrm{K})]=0.8-0.9$ and $X_{\text {or }}[=$ molar $\mathrm{K} /(\mathrm{Na}+\mathrm{Ca}+\mathrm{K})]$ generally below 0.01. Some samples exhibit significant compositional variation with $X_{\mathrm{ab}} 0.83-0.88$ and $0.90-0.93$ in individual thin sections. Calculated $\mathrm{Fe}_{2} \mathrm{O}_{3}$ contents are $<0.1$ wt.\%. Large plagioclase grains in sample T29 are zoned with $X_{\text {an }}$ increasing towards the rim (Fig. 5c).

Staurolite poikiloblasts $(<0.2 \mathrm{~mm})$ have $3.9-4.0$ c.p.f.u. Si, $8.67-8.82$ Al c.p.f.u., $1.32-1.46 \mathrm{Fe}^{2+}$ c.p.f.u. (23 oxygens) and $X_{\mathrm{Fe}}$ of around 0.8. Fe-Ti oxides are compositionally homogeneous. Ti in ilmenite is generally close to 2 c.p.f.u. and Fe is typically around 1.9 c.p.f.u. (6 O). Clinozoisite grains within the Ca-rich Schwanberger Gneiss (Sample T29) are rich in $\mathrm{Al}\left(2.68-2.72\right.$ c.p.f.u.) and have $\mathrm{Fe}^{3+} /\left(\mathrm{Fe}^{3+}+\mathrm{Al}^{\mathrm{Ml}}\right)$ values of $\sim 0.17$.

\section{Footwall samples}


Small fractured garnets $(<0.5$ millimetre) are commonly weakly zoned with decreasing $X_{\mathrm{alm}}$ and $X_{\text {spss }}$ from core to rim. Increasing $X_{\mathrm{alm}}$ and $X_{\text {spss }}$ and decreasing $X_{\mathrm{py}}$ in the outermost rim of large garnet porphyroblasts in contact with matrix biotite suggest some retrograde diffusional re-equilibration. $X_{\mathrm{Fe}}$ in garnet is above 0.65 and Mn-contents are typically low ( $<0.07$ c.p.f.u.). There is significant compositional variability in garnet compositions within individual samples with $X_{\mathrm{gr}}$ varying between 0.08 and 0.28 . The chemical composition of fractured sub-mm-sized garnet is similar to the composition of porphyroblast rims. In sample T22, garnet is enriched in $\mathrm{Fe}\left(X_{\mathrm{Fe}}=0.77-0.81\right)$ and contains less $\mathrm{Ca}$ and $\mathrm{Mn}$ than garnet in most other samples. A large, corroded garnet porphyroblast in sample T22 has a core enriched in $\operatorname{Mn}\left(X_{\text {spss }}=0.10-0.12\right)$ and $\mathrm{Fe}\left(X_{\mathrm{alm}}>\right.$ $0.72)$ and relatively depleted in $\mathrm{Ca}(<0.2$ c.p.f.u. $)$.

Matrix biotite and biotite within garnet pressure shadows generally have $X_{\mathrm{Fe}}$ of $0.38-0.44$, and higher $\mathrm{Ti}(0.1-0.2$ c.p.f.u.) and lower $\mathrm{Si}(\mathrm{Si}=2.74-2.8$ c.p.f.u. $)$ compared to hangingwall samples. $\mathrm{Al}$ on the M1-site in biotite ( $\sim 0.35$ c.p.f.u.) is similar to samples from the hangingwall. Muscovite exhibits a range of textures; individual grains are unzoned. Muscovite typically has > 3.2 Si c.p.f.u., but contents may be as low as 3.1 c.p.f.u. (e.g. sample T21 and T31). Al-contents are mostly 2.4-2.5 Al c.p.f.u., although muscovite in sample T21 has higher Al-contents ( 2.7 c.p.f.u.). Most have $0.1-0.2 \mathrm{Mg}$ c.p.f.u. and $<0.1$ c.p.f.u. Fe. In contrast to white mica in hangingwall samples, footwall samples generally have lower $X_{\mathrm{Na}}(<0.05)$, although in samples T21 and T31 $X_{\mathrm{Na}}$ is up to 0.2. White mica replacing kyanite has similar $\mathrm{Si}$-contents $(\mathrm{Si}=3.16-3.2$ c.p.f.u.), slightly higher Al-contents $(\mathrm{Al}=2.55-2.65$ c.p.f.u $)$ and similar $\mathrm{Mg}$-contents $(\mathrm{Mg}=0.15-0.2$ c.p.f.u.) compared with those occurring in other microstructural positions. 
Small, anhedral matrix plagioclase grains are either unzoned or weakly zoned, with increased $X_{\text {an }}$ in the outermost rims (Fig. 5d). $X_{\text {ab }}$ is typically $0.81-0.93$ and $X_{\text {or }}<0.02$. Ferric iron contents are below $0.05 \mathrm{wt} \%$. Plagioclase exhibits significant compositional variations within individual samples. In sample T24, for example, $X_{\mathrm{ab}}$ varies between 0.70 and 0.85 .

\section{MINERAL EQUILIBRIA MODELLING}

A forward modelling approach was used in order to constrain peak metamorphic $P-T$ conditions to evaluate consistency with subsequent thermobarometric calculations. Pseudosections were modelled in the $\mathrm{Na}_{2} \mathrm{O}-\mathrm{CaO}-\mathrm{K}_{2} \mathrm{O}-\mathrm{FeO}-\mathrm{MgO}-\mathrm{Al}_{2} \mathrm{O}_{3}-\mathrm{SiO}_{2}-\mathrm{H}_{2} \mathrm{O}-$ $\mathrm{TiO}_{2}-\mathrm{O}$ (NCKFMASHTO) model system for two hangingwall samples, T18 and T29, the bulk compositions of which are based on analyses using a Philips MagiX Pro 4kW sequential X-ray fluorescence spectrometer at the Institute for Geoscience, University of Mainz (Table 4). Loss-on-ignition (LOI) totals were used as a direct proxy for $\mathrm{H}_{2} \mathrm{O}$ contents and $2.5 \%$ of the total $\mathrm{FeO}$ was converted to $\mathrm{Fe}_{2} \mathrm{O}_{3}$. The following mineral $a-X$ models were used: garnet, biotite and silicate melt (White et al., 2007), staurolite and epidote (Holland \& Powell, 1998), white micas (Coggon \& Holland, 2002), plagioclase and K-feldspar (Holland \& Powell, 2003), ilmenite and hematite (White et al., 2000). Mineral abbreviations are as follows: $\mathrm{g}=$ garnet; $\mathrm{pa}=$ paragonite; $\mathrm{bi}=$ biotite; $\mathrm{mu}=$ muscovite; sill = sillimanite; $\mathrm{ky}=$ kyanite; $\mathrm{st}=$ staurolite; $\mathrm{ksp}=$ alkali feldspar; $\mathrm{pl}=$ plagioclase feldspar; $\mathrm{ru}=$ rutile $;$ ilm = ilmenite; hem = hematite; $\mathrm{ep}=$ epidote; $\mathrm{q}=$ quartz and liq $=$ silicate melt. 
Figure 6 shows NCKFMASHTO $P-T$ pseudosections for the two modelled compositions (T18 in Fig. 6a and T29 in Fig. 6b). Also shown are the calculated compositional isopleths of $X_{\mathrm{Fe}}$ and $X_{\mathrm{Ca}}$ in garnet, $X_{\mathrm{Na}}$ in muscovite and $X_{\mathrm{Ca}}$ in plagioclase for comparison.

Sample T18 is a metapelitic schist with the inferred peak assemblage garnetbiotite-muscovite-plagioclase-kyanite-rutile-ilmenite-quartz-liquid or $\mathrm{H}_{2} \mathrm{O}$. Small poikiloblastic grains of staurolite (Fig. 3e) are interpreted to be of retrograde origin. This peak assemblage coexisting with $\mathrm{H}_{2} \mathrm{O}$ (i.e. subsolidus) occupies a small region in $P-T$ space between $\sim 650$ and $670{ }^{\circ} \mathrm{C}$ and $\sim 10$ and 11 kbar (Fig. 6a). The equivalent meltbearing (i.e. suprasolidus) assemblage field occupies a much larger area in $P-T$ at temperatures in excess of $670{ }^{\circ} \mathrm{C}$ and pressures of around $10.5-13.5 \mathrm{kbar}$. The stability field of staurolite occupies the low $P-T$ (lower left) portion of pseudosection (Fig. 6a). Measured mineral compositions within this sample are consistent with $P-T$ conditions of around $12 \mathrm{kbar}$ and $700^{\circ} \mathrm{C}$ (white star).

Sample T29 is a Ca-rich metapelitic sample from the Schwanberger Gneiss complex. In Fig. 6b, the inferred peak assemblage for this rock is garnet-biotitemuscovite-plagioclase-clinozoisite-rutile-quartz-liquid or $\mathrm{H}_{2} \mathrm{O}$. The calculations show two large quadrivariant fields including these minerals, one subsolidus (with $\mathrm{H}_{2} \mathrm{O}$ ) and the other suprasolidus (with melt). Measured mineral compositions within this sample are also consistent with $P-T$ conditions of around $12 \mathrm{kbar}$ and $700^{\circ} \mathrm{C}$ (white star).

\section{ABSOLUTE AND RELATIVE THERMOBAROMETRY}


Calculations were performed using THERMOCALC v3.33 (Powell \& Holland, 1988) and the internally consistent dataset (ds55) of Holland \& Powell (1998; November 2003 update). Conventional thermobarometric calculations (inverse modelling) and the calculation of absolute $P-T$ conditions use the average $P-T$ method (avPT) of Powell \& Holland (1994). Thereafter, pressure differences and their associated uncertainties were calculated following the method of Worley \& Powell (2000). Average pressures (avP) for samples were calculated using the activities of the relevant mineral end members as input. Only garnet, biotite, plagioclase and muscovite end members were considered as these minerals are common to all samples. End member activities were calculated from the raw EPMA data using the software AX (http://www.esc.cam.ac.uk/research/researchgroups/holland/ax). Importantly, only $\mathrm{H}_{2} \mathrm{O}$-absent equilibria were considered as the activity of $\mathrm{H}_{2} \mathrm{O}$ is largely unconstrained.

The relative $P-T$ approach $(\triangle P T)$ of Worley \& Powell (2000) is based on the avPT method. The calculation of a pressure difference $(\Delta P)$ between a common assemblage in two samples (A and B), including uncertainties, involves the following steps. Firstly, average pressures are calculated at a fixed temperature to generate values for av $P_{\mathrm{A}}$ and $\operatorname{av} P_{\mathrm{B}}$. Each of these values has an associated uncertainty and statistical fit, generating values for $1 \sigma(\operatorname{av} P)_{\mathrm{A}}, 1 \sigma(\operatorname{av} P)_{\mathrm{B}}$ and $\sigma_{\mathrm{fit}}(\operatorname{av} P)_{\mathrm{A}}, \sigma_{\mathrm{fit}}(\operatorname{avP})_{\mathrm{B}}$, respectively. From these, standard deviations may be calculated such that $\mathrm{sd}_{\mathrm{A}}=1 \sigma(\operatorname{av} P)_{\mathrm{A}} / \sigma_{\mathrm{fit}}(\operatorname{av} P)_{\mathrm{A}}$ and $\mathrm{sd}_{\mathrm{B}}=$ $1 \sigma(\operatorname{av} P)_{\mathrm{B}} / \sigma_{\text {fit }}(\mathrm{avP})_{\mathrm{B}}$. The pressure difference at a fixed temperature $\left(\Delta P_{\mathrm{T}}\right)$ is then simply the difference between the calculated pressures (i.e. $\left(\Delta P=\operatorname{av} P_{\mathrm{A}}-\mathrm{av} P_{\mathrm{B}}\right)$ and the $1 \sigma$ 
uncertainty on $\Delta P$ is $\sqrt{ }\left(\mathrm{sdA}^{2}+\mathrm{sdB}^{2}\right)$. The result is doubled to give the $2 \sigma_{\Delta P}$ uncertainty. The final result at a given temperature is then $\Delta P \pm 2 \sigma_{\Delta P}$.

\section{Average pressure calculations (avP)}

Average pressure calculations are based on a set of five independent end-member reactions: (1) muscovite +2 phlogopite +6 quartz $=$ pyrope +3 celadonite; (2) 2 eastonite +6 quartz $=$ pyrope + muscovite + celadonite; (3) muscovite +2 annite +6 quartz $=$ almandine +3 Fe-celadonite; (4) 3 anorthite + annite $=$ grossular + almandine + muscovite; and (5) 3 anorthite + phlogopite $=$ pyrope + grossular + muscovite and were calculated at $675^{\circ} \mathrm{C}, 700{ }^{\circ} \mathrm{C}, 725^{\circ} \mathrm{C}$ and $750{ }^{\circ} \mathrm{C}$. Average pressures with $2 \sigma$ errors for the eighteen investigated samples are shown in Fig. 7 (see also Table 5). The av $P$ values are positively correlated with $T$ (Fig. 7) although variations are small. Hangingwall samples record average pressures of $\sim 11-17 \mathrm{kbar}$ and footwall samples $\sim 11-19 \mathrm{kbar}$.

The average of the $2 \sigma$ uncertainties on the av $P$ calculations decreases slightly from $2.46 \mathrm{kbar}$ at $675^{\circ} \mathrm{C}$ to $2.31 \mathrm{kbar}$ at $750^{\circ} \mathrm{C}$. In addition, uncertainties for hangingwall samples are slightly lower (1.8-2.5 kbar) than for footwall samples $(2.1-2.9$ kbar), and the $\sigma_{\text {fit }}$ for the former are accordingly slightly lower (0.88-1.36) than for the latter (1.16-1.54). At $700{ }^{\circ} \mathrm{C}$, the uncertainties on the absolute pressure calculations range from 1.8 to 2.9 kbar. As a consequence, all calculated average pressures overlap within their $2 \sigma$ uncertainties and no statistically meaningful pressure differences between samples can be recognised. 


\section{Pressure differences $(\Delta P)$}

The results of relative pressure differences $(\Delta P)$ with associated $2 \sigma$ uncertainties at different temperatures are shown in Fig. 8. Pressure differences for the full set of samples were calculated relative to hangingwall sample PG40 (Figs 8a,b; Table 6a) then, for a more spatially restricted sample set, relative to T18 (Figs 8c,d; Table 6b; see discussion). Sample PG40 was used as a baseline reference not only because the calculated av $P$ for this sample is closest to the mean of all av $P$ but also because this sample preserves a particularly well-equilibrated microstructure. Based on the modelled geometry of the Plattengneiss (Putz et al., 2006), the estimated distance of sample locations vertically above or below the Plattengneiss boundary is generally 200-500 m (Fig. 1). Taking into account the thickness of the Plattengneiss $(250-600 \mathrm{~m})$, the maximum structural separation between samples is estimated at $1500 \mathrm{~m}$ normal to the shear zone boundaries, but in most cases is considerably less. This equates to a maximum lithostatic pressure difference between samples of $\sim 0.4 \mathrm{kbar}$ assuming a normal crustal density for the rocks $\left(2.7 \mathrm{gcm}^{-3}\right)$

The overall pattern of pressure differences is complex (Fig. 8a,b), with some samples recording pressures that differ significantly from sample PG40, whereas others are statistically indistinguishable. There are no significant differences between the results at $700{ }^{\circ} \mathrm{C}$ and $750{ }^{\circ} \mathrm{C}$, indicating the calculations are essentially temperature independent. 
The $2 \sigma$ uncertainties on the calculated pressure differences are 0.91 to $1.03 \mathrm{kbar}$, around half those on the average pressure calculations.

The footwall samples, T15, T16, T31 and PG21 from the central Koralpe complex (Fig. 1c) record pressures that are statistically higher than those of PG40, in which $\Delta P>$ $1.5 \pm \sim 1 \mathrm{kbar}$, even when the vertical distance between samples is considered. However, samples T21, T22, T24 and T26, collected from the southern limb of the Schwanberger synform (Fig. 1) are statistically indistinguishable from PG40 (Fig. 8). All hangingwall samples have $\Delta P$ S that are statistically indistinguishable from PG40 except T29, which exhibits a significant pressure difference $(\Delta P=-1.8 \pm 0.9 \mathrm{kbar})$.

\section{DISCUSSION}

\section{Relative pressure differences $(\Delta P)$}

Due to the large $2 \sigma$ uncertainties on the av $P$ calculations of between 1.8 and $2.9 \mathrm{kbar}$ (Fig. 7, Table 5), all results overlap within these errors and pressures calculated using this method are statistically indistinguishable. However, $\Delta P$ results calculated using the method of Worley \& Powell (2000) indicate statistically significant pressure differences between hangingwall sample PG40 and four footwall samples (T15, T16, T31 \& PG21) (Fig. 8, Tables 6a). There is also a pressure difference between PG40 and the nearby hangingwall sample T29 $\left(\Delta P=-1.82 \pm 0.93 \mathrm{kbar}\right.$ at $\left.700^{\circ} \mathrm{C}\right)$, although hangingwall 
sample T18 from the same area shows no identifiable pressure difference $(\Delta P=-0.74 \pm$ $1.03 \mathrm{kbar}$ at $\left.700^{\circ} \mathrm{C}\right)$ (Fig. 1c).

Hangingwall sample T18 was used as a basis for the calculation of a smaller dataset considering only those samples geographically close to this sample (Fig. 1c); the results are shown in Figs $8 \mathrm{c}, \mathrm{d}$ and Table $6 \mathrm{~b}$. With the possible exception of sample T24, the calculated pressure differences between sample T18 and nearby footwall samples indicate statistically significant pressure differences, differences that were indistinguishable when using sample PG40 as a baseline (Fig. 8).

In summary, while there are clearly some complications in the pattern indicated by the $\Delta P$ calculations (e.g. the statistically significant pressure differences between the two hangingwall samples PG40 and T29), the results suggest that there are pressure variations across the Plattengneiss shear zone that are statistically significant and cannot be accounted for by the structural separation or geographical location of the samples. Depending of which sample is used as a baseline, recorded pressures on either side of the Plattengneiss differ by up to 3 kbar (Fig. 8).

Before discussing the potential implications of these results, it is important to consider some caveats. Firstly, the recorded pressure differences may have resulted from diachronous metamorphism (Fraser et al., 2000), perhaps related to rapid exhumation of deeply buried crust and/or variable interaction of the rocks with externally derived fluids that potentially infiltrated along the shear zone as it was actively deforming. Secondly, there is a clear inconsistency between the geological maps of Beck-Mannagetta (1980) and Kleinschmidt et al. (1989), both of which show Plattengneiss rocks cropping out some kilometres south of Krakaberg and Krennkogel, and the model of Putz et al. (2006), 
which indicates only footwall rocks in this area. Thirdly, post-metamorphic movements along the Plankogel detachment may have disturbed results from samples close to this fault system.

Additional factors that may have contributed to the recorded pressure variations include differential stresses on a thin-section scale, which can have a strong influence on geobarometric calculations (Tenczer et al., 2001). Extreme flattening of the shear zone after metamorphic equilibration may also have been important, which is perhaps supported by the scarcity of reliable shear sense indicators in the mylonite and the adjacent wall rocks. However, a mechanical juxtaposition of various lithologies and rocks from different depths at any stage of the tectonometamorphic evolution can probably be ruled out (e.g. Bruand et al., 2009; Schuster \& Stüwe, 2008), as eclogites and their metapelitic host rocks share a common Eoalpine history. This excludes any process that mixes rocks of different origins and formation conditions together during their evolution.

\section{Constraints on peak $P-T$ and the $P-T$ path}

In the $P-T$ pseudosection for composition T18, the fields for the inferred peak assemblage garnet-biotite-muscovite-plagioclase-kyanite-rutile-ilmenite-quartz with either $\mathrm{H}_{2} \mathrm{O}$ or melt cover a wide area in $P-T$ (Fig. 6a). However, calculated compositional isopleths for garnet, biotite and muscovite within the peak assemblage fields are broadly consistent with measured values, constraining peak metamorphic conditions to 11-13 kbar and $680-720^{\circ} \mathrm{C}$. The inferred peak mineral assemblage in sample T29 (garnet- 
biotite-muscovite-plagioclase -clinozoisite-rutile-quartz) also occupies a large $P-T$ field (Fig. 6b), within which the measured composition of minerals imply peak conditions of around $12 \mathrm{kbar}$ at $690-710^{\circ} \mathrm{C}$. However, the compositional zoning in the rim of plagioclase (Fig. 5c) and the scatter in $X_{\mathrm{Ca}}$ values in garnet from 0.40 to 0.31 in this sample suggest the rocks reached pressures much higher than those recorded at the thermal peak (Fig. 6b). For both of the modelled compositions, the inferred peak metamorphic conditions are within the suprasolidus (melt-present) region, although calculated melt fractions are low $(<5$ mol.\%). Clear evidence for the former presence of melt in these samples is lacking, although deformation, fluid-rock interaction, recrystallization and retrograde reactions may have erased any such evidence.

Figure 9 summarises the constraints on peak $P-T$ conditions imposed by both the forward and inverse modelling approaches. The multivariant peak assemblage fields of samples T18 and T29 overlap with the $1 \sigma$ error ellipses of calculated av $P T$ and the av $P$ for the same samples consistent with peak metamorphic conditions of around $700^{\circ} \mathrm{C}$ and 12-13 kbar, consistent with previous estimates (e.g. Stüwe, 1994; Stüwe \& Powell, 1995; Gregurek et al., 1997; Tenczer et al., 2006; Tenczer \& Stüwe, 2003).

Although caution should be exercised in the interpretation of timing relations using inclusions within porphyroblasts (Vernon et al., 2008), inclusions of staurolite and paragonite within the core of a large garnet porphyroblast in sample T4 (Fig. 3a) potentially provide information on the prograde $P-T$ path. Staurolite and paragonite do not occur as a matrix phase in this sample, suggesting they were not stable at the metamorphic peak. Rutile occurs both within the matrix and within the inclusion-poor rim of this garnet porphyroblast. Although the phase equilibria modelling results suggest 
that paragonite can occur at pressures both higher and lower than the recorded peak metamorphic conditions, the presence of staurolite (with quartz) implies temperatures below $650{ }^{\circ} \mathrm{C}$ and pressures $<12 \mathrm{kbar}$. Rutile is indicative of pressures above 10-11 kbar. These observations are consistent with the early prograde growth of staurolite and paragonite (with garnet), followed by the growth of rutile and an evolution to the peak $P-$ $T$ conditions within the rutile stability field but outside that of staurolite and paragonite.

The late growth of staurolite in the matrix of some hangingwall samples provides a constraint on retrograde metamorphism (e.g. Fig. 3e). In sample T18, the presence of staurolite constrains a portion of the retrograde path to conditions of $\sim 8-9 \mathrm{kbar}$ and 600 $645^{\circ} \mathrm{C}$ (arrow in Fig. 6a). The presence of kyanite and the absence of sillimanite in the rocks of this study likely constrain the high $T$ portion of the retrograde path to the kyanite stability field (cf. Stüwe \& Powell, 1995).

The constraints detailed above are consistent with a steep clockwise $P-T$ path that intersected the staurolite stability field during both the prograde and retrograde evolution (Fig. 10). In view of the pressure differences between hanging and footwall implied by the relative pressure calculations, the prograde segment of the $P-T$ path for hangingwall and footwall samples would have been different - separated in depth equivalent to about 1- kbar, as shown on Fig. 10. However, during deformation at peak metamorphic conditions, these $P-T$ paths would have converged, and the retrograde segment of both should have been near identical. The inferred $P-T$ path is consistent with those suggested previously for the region (e.g. Stüwe \& Powell, 1995; Tenczer et al., 2006; Thöni, 1999; Thöni \& Jagoutz, 1992) and comparable to those proposed for the Adula nappe (Dale \& Holland, 2003; Meyre et al., 1999). 


\section{The significance of the Plattengneiss and implications for exhumation models}

Accepting the caveats discussed above, the $\Delta P$ results show that the Plattengneiss shear zone is likely to have been substantially thicker than its present thickness prior to its initial deformation. In other words, the shear zone was flattened substantially during shearing, reducing its total thickness (from up to $10 \mathrm{~km}$ ) to $<1 \mathrm{~km}$. Deformation and volume loss most likely was followed by near-isothermal decompression between the pressure and the temperature peak (Kurz et al., 2002).

The predictions of these interpretations are profound as they imply substantial volume loss from inside the shear zone during Eoalpine deformation. As the stretching lineation is oriented north-south over most of the shear zone, such volume loss during pure shear flattening is likely to have occurred by either northwards or southwards flow of material from inside the shear zone. In order to be consistent with the shear sense indicators documented by Kurz et al., (2002) in the hanging and footwall of the shear zone (see Fig. 1d), we suggest that this channel flow type extrusion (with a reversal of shear sense within the Plattengneiss shear zone itself, (Fig. 1d)) was south directed removing material from between hanging and footwall downward during the south directed Eoalpine subduction (Fig. 11).

This is consistent with a model of slab extraction in the style suggested by Froitzheim et al. (2003). It is conceivable that the material removed during the flow contained substantial amounts of eclogites, resulting in reversal of the buoyancy of the 
Koralpe and thus causing rapid exhumation immediately following the extrusion. If so, the Plattengneiss mylonite is an extraction fault in the sense of Froitzheim et al. (2006) and formed in direct connection with the Eoalpine subduction (Stüwe \& Schuster, 2010).

\section{ACKNOWLEDGEMENTS}

We thank S. Buhre and N. Groschopf for their technical assistance during EPMA analyses. Helpful and insightful comments from an anonymous reviewer are gratefully acknowledged. T.E. extends his thanks to S. Fischer, A. Zirkler and C. Heinz for numerous discussions. 


\section{REFERENCES}

Beck-Mannagetta, P., 1980. Geologische Karte der Republik Österreich 1:50.000, Blatt 188 Wolfsberg. Herausgegeben von der Geologischen Bundesanstalt, Wien, 1980.

Bruand, E., Stüwe, K. \& Proyer, A., 2009. Pseudosection modelling for a selected eclogite body from the Koralpe (Hohl), Eastern Alps. Mineralogy and Petrology, 99, 75-87.

Cartwright, I. \& Barnicoat, A.C., 2002. Petrology, geochronology and tectonics of shear zones in the Zermatt-Saas and Combin zones of the Western Alps. Journal of Metamorphic Geology, 20, 263-281.

Chemenda, A.I., Mattauer, M., Malavieille, J. \& Bokun, A.N., 1995. A mechanism for syn-collisional deep rock exhumation and associated normal faulting: results from physical modelling. Earth and Planetary Science Letters, 132, 225-232.

Coggon, R. \& Holland, T. J. B., 2002. Mixing properties of phengitic micas and revised garnet-phengite thermobarometers. Journal of Metamorphic Geology, 20, 7, 683696.

Dale, J. \& Holland, T.J.B., 2003. Geothermobarometry, $P-T$ paths and metamorphic field gradients of high-pressure rocks from the Adula Nappe, Central Alps. Journal of Metamorphic Geology, 21, 813-829. 
Faryad, S.W. \& Hoinkes, G., 2003. $P-T$ gradient of Eo-Alpine metamorphism within the Austroalpine basement units east of the Tauer Window (Austria). Mineralogy and Petrology, 77, 129-159.

Frank, W., 1987. Evolution of the Austroalpine elements in the Cretaceous. In: Geodynamic of the Eastern Alps (eds Flügel, H. \& Faupl, P.), pp. 379-406. Deuticke, Vienna.

Fraser, G., Worley, B. \& Sandiford, M., 2000. High-precision geothermobarometry across the High Himalayan metamorphic sequence, Langtang Valley, Nepal. Journal of Metamorphic Geology, 18, 6, 665-681.

Frey, M., Desmons, J. \& Neubauer, F., 1999. The new metamorphic map of the Alps: Introduction. Schweiz. Mineral. Petrogr. Mitt., 79, 1-4.

Froitzheim, N., Pleuger, J., Roller, S. \& Nagel, T.J., 2003. Exhumation of high- and ultrahighpressure metamorphic rocks by slab extraction. Geology, 31, 925-928.

Froitzheim, N., Pleuger, J. \& Nagel, T.J., 2006. Extraction faults. Journal of Structural Geology, 28, 1388-1395.

Gregurek, D., Abart, R. \& Hoinkes, G., 1997. Contrasting Eoalpine $P-T$ evolutions in the southern Koralpe, Eastern Alps. Mineralogy and Petrology, 60, 61-80.

Habler, G. \& Thöni, M., 2001. Preservation of Permo-Triassic low-pressure assemblages in the Cretaceous high-pressure metamorphic Saualpe crystalline basement (Eastern Alps, Austria). Journal of Metamorphic Geology, 19, 679-697. 
Habler, G., Thöni, M., Sölva, H., 2006. Tracing the high pressure stage in the polymetamorphic Texel Complex (Austroalpine basement Unit, Eastern Alps): an interdisciplinary approach. Mineralogy and Petrology, 88, 269-296

Hatley E., 2010. Geometry of the Platten Gneiss shear zone, Austria, from quartz c-axis fabrics and 3D modeling. MSc thesis, University of Austin, Texas, USA.

Hatley, E., Carlson W.D., Stuewe K. \& Helper M., 2009. Assessing the kinematic significance of the Plattengneis, a major intracrustal transport horizon in the Koralpe region of the Eastern Alps. GSA abstract.

Hauy, R.J., 1822. Traité de Mineralogie, $2^{\text {nd }}$ edition. Bachelier, Paris.

Hodges, K. \& McKenna, L., 1987. Realistic propagation of uncertainties in geologic thermobarometry. American Mineralogist, 72, 671-680.

Holland, T.J.B. \& Powell, R., 1998. An internally consistent thermodynamic data set for phases of petrological interest. Journal of Metamorphic Geology, 16, 309-343.

Holland, T.J.B. \& Powell, R., 2003. Activity-composition relations for phases in petrological calculations: an asymmetric multicomponent formulation. Contributions to Mineralogy and Petrology, 145, 492-501.

Kleinschmidt, G., Seeger, M., Thiedig, F., 1989. Geologische Karte der Republik Österreich 1:50.000, Blatt 205 Sankt Paul im Lavanttal. Herausgegeben von der Geologischen Bundesanstalt, Wien, 1989.

Kohn, M. \& Spear, F.S., 1991. Error propagation for barometers: 2. Application to rocks. American Mineralogist, 76, 138-147. 
Kurz, W., Neubauer, F. \& Unzog, W., 1999. Evolution of Alpine eclogites in the Eastern Alps: Implications for Alpine geodynamics. Physics and Chemistry of the Earth, Part A: Solid Earth and Geodesy, 24, 667-674.

Kurz, W., Fritz, H., Tenczer, V. \& Unzog, W., 2002. Tectonometamorphic evolution of the Koralm Complex (Eastern Alps): constraints from microstructures and textures of the 'Plattengneis' shear zone. Journal of Structural Geology, 24, 1957-1970.

Meyre, C., De Capitani, C., Zack, T. \& Frey, M., 1999. Petrology of High-Pressure Metapelites from the Adula Nappe (Central Alps, Switzerland). Journal of Petrology, 40, 199-213.

Miller, C. \& Thoni, M., 1997. Eo-alpine eclogitisation of Permian MORB-type gabbros in the Koralpe (Eastern Alps, Austria): new geochronological, geochemical and petrological data. Chemical Geology, 137, 283-310.

Oberhänsli, R. \& Goffé, B., 2004. Explanatory notes to the map: metamorphic structure of the Alps Introduction. Mitteilungen der Österreichischen Mineralogische Gessellschaft, 149, 115-123.

Putz, M., Stüwe, K., Jessell, M. \& Calcagno, P., 2006. Three-dimensional model and late stage warping of the Plattengneis Shear Zone in the Eastern Alps. Tectonophysics, 412, 87-103.

Powell, R. \& Holland, T.J.B., 1988. An internally consistent dataset with uncertainties and correlations: 3. Applications to geobarometry, worked examples and a computer program. Journal of Metamorphic Geology, 6, 173-204. 
Powell, R. \& Holland, T.J.B., 1994. Optimal geothermometry and geobarometry. American Mineralogist, 79, 120-133.

Powell, R. \& Holland, T. J. B., 2008. On thermobarometry. Journal of Metamorphic Geology, 26, 155-179.

Roffeis, C., 2008. Bestimmung und Interpretation von vertikalen Druckgradienten Über die Plattengneisscherzone. Karl-Franzens Universität Graz. Unpublished MSc thesis.

Schuster, R. \& Stüwe, K., 2008. Permian metamorphic event in the Alps. Geology, 36, $603-606$.

Spear, F.S., 1995. Metamorphic Phase Equilibria and Pressure-Temperature-Time Paths. Monographs. Washington, D.C.. Mineralogical Society of America.

Stüwe, K., 1994. Some Calculated Thermodynamic Pseudosections from the Plattengneis and Other Rocks of the Koralm Complex, Eastern Alps. Mitteilungen des Naturwissenschaftlichen Vereins für Steiermark. 1, 29-39.

Stüwe, K., 1998. Heat sources of Cretaceous metamorphism in the Eastern Alps - a discussion. Tectonophysics, 287, 251-269.

Stüwe, K. \& Powell, R., 1995. P-T Paths from modal proportions: application to the Koralm Complex, Eastern Alps. Contributions to Mineralogy and Petrology, 119, 83-93.

Stüwe, K. \& Schuster, R., 2010. Initiation of subduction in the Alps: Continent or ocean? Geology, 38, 175-178. 
Tenczer, V., Stüwe, K. \& Barr, T.D., 2001. Pressure anomalies around cylindrical objects in simple shear. Journal of Structural Geology, 23, 777-788.

Tenczer, V., Powell, R. \& Stüwe, K., 2006. Evolution of $\mathrm{H}_{2} \mathrm{O}$ content in a polymetamorphic terrane: the Plattengneiss Shear Zone (Koralpe, Austria). Journal of Metamorphic Geology, 24, 281-295.

Tenczer, V. \& Stüwe, K., 2003. The metamorphic field gradient in the eclogite type locality, Koralpe region, Eastern Alps. Journal of Metamorphic Geology, 21, 377393.

Thöni, M., with contributions by Hoinkes, G., 1983. The thermal climax of Early Alpine metamorphism in the Austroalpine thrust sheet. Mem Sci Geol, 36, 211-238.

Thöni, M., 1999. A review of geochronolgical data from the Eastern Alps. Schweizer Mineralogische und Petrographische Mitteilungen, 79, 209-230.

Thöni, M. \& Jagoutz, E., 1992. Some new aspects of dating eclogites in orogenic belts: $\mathrm{Sm}-\mathrm{Nd}, \mathrm{Rb}-\mathrm{Sr}$, and $\mathrm{Pb}-\mathrm{Pb}$ isotopic results from the Austroalpine Saualpe and Koralpe type-locality (Carinthia/Styria, southeastern Austria). Geochimica et Cosmochimica Acta, 56, 347-368.

Thöni, M. \& Jagoutz, E., 1993. Isotopic constraints for eo-Alpine high-P metamorphism in the Austroalpine nappes of the Eastern Alps: bearing on Alpine orogenesis. Schweizer Mineralogische und Petrographische Mitteilungen, 73, 177-189. 
Thöni, M. \& Miller, C., 1996. Garnet Sm-Nd data from the Saualpe and the Koralpe (Eastern Alps, Austria): chronological and $P-T$ constraints on the thermal and tectonic history. Journal of Metamorphic Geology, 14, 453-466.

Vernon, R.H., White, R.W. \& Clarke, G.L., 2008. False metamorphic events inferred from misinterpretation of microstructural evidence and $P-T$ data. Journal of Metamorphic Geology, 26, 437-449

von Blanckenburg, F. \& Davies, J.H., 1995. Slab breakoff: A model for syncollisional magmatism and tectonics in the Alps. Tectonics, 14, 120-131

White, R.W., Powell, R., Holland, T.J.B. \& Worley, B., 2000. The effect of $\mathrm{TiO}_{2}$ and $\mathrm{Fe}_{2} \mathrm{O}_{3}$ on metapelitic assemblages at greenschist and amphibolite facies conditions: mineral equilibria calculations in the system $\mathrm{K}_{2} \mathrm{O}-\mathrm{FeO}-\mathrm{MgO}-\mathrm{Al}_{2} \mathrm{O}_{3}-\mathrm{SiO}_{2}-\mathrm{H}_{2} \mathrm{O}-$ $\mathrm{TiO}_{2}-\mathrm{Fe}_{2} \mathrm{O}_{3}$. Journal of Metamorphic Geology, 18, 497-511.

White, R. W., Powell, R. \& Holland, T. J. B., 2007. Progress relating to calculation of partial melting equilibria for metapelites. Journal of Metamorphic Geology, 25, 511527.

Worley, B. \& Powell, R., 2000. High-precision relative thermobarometry: theory and a worked example. Journal of Metamorphic Geology, 18, 91-101. 


\section{FIGURE CAPTIONS}

Fig. 1. (a) Simplified geological sketch map of the major tectonometamorphic units in the Eastern Alps. (b) The Koralpe-Saualpe complex near Graz with a simplified sketch map of the Plattengneiss (black). (c) Enlarged sketch map showing the distribution of the Plattengneiss and its hangingwall and footwall along with the location of studied samples. (d) Geological cross section as shown on (c). Medium grey is Plattengneiss, light grey is hangingwall and dark grey is footwall. Eclogite bodies, shown schematically as white ellipses with bold stroke, occur both above and below the shear zone. The black dots and arrows show the location of shear sense indicators as documented by Kurz et al. (2002) and Hatley (2010). The large grey arrows indicate the kinematic interpretation of Kurz et al. (2002). However, the measured shear sense indicators are also consistent with an interpretation as a southward extruding channel, an interpretation preferred here (inset circle).

Fig. 2. Field relations of the most common rock types in the crystalline basement of the Koralpe. (a) Strongly lineated, mylonitic Plattengneiss. (b) Strongly deformed metapelitic gneiss with pinch-and-swell boudins of more competent layers close to the Plattengneiss in the footwall. (c) Porphyroblastic garnet-staurolite micaschist from the hangingwall of the Plattengneiss near the Rehbock hut. (d) Micaschist with coarse kyanite aggregates pseudomorphs after andalusite that grew during Permian metamorphism. (e) Garnetbearing calcareous schist. (f) In-situ transition from gabbro (right) to high-pressure eclogite (left) (GEOPARK in Glashütten). 
Fig. 3. Photomicrographs showing mineral and microstructural relationships in the hangingwall micaschists. (a) Garnet porphyroblast with inclusions of staurolite and paragonite in the core and rutile in the rim (Sample T4). (b) Garnet with inclusions of rutile and matrix rutile with a corona of ilmenite (Sample T5). (c) Fragmented, inclusionpoor garnet with a kyanite crystal at its margin (Sample T18). (d) Large garnet porphyroblast with abundant inclusions surrounded by fractured garnet. (e) Staurolite grain between kyanite and garnet (Sample T18). (f) Plagioclase porphyroblast containing inclusions of quartz in a matrix of white mica and biotite. Clinozosite overprints the micaceous matrix (Sample T29).

Fig. 4. Photomicrographs showing the most important and representative microstructures in the footwall rocks. (a) Permian biotite porphyroblast is replaced by Cretaceous garnet growing on the mica cleavage planes. (b) Protomylonitic quartz matrix in a garnetbearing rock. Biotite is exclusively growing in pressure shadows of garnet and kyanite pseudomorphs presumably after Permian andalusite are present. (c) Garnet replacing biotite enclosing feldspar grains. (d) Idiomorphic garnet grains replace white mica clast. Biotite replaces the white mica along edges, cleavage planes and along contacts with the new garnet generation. (e) Garnet also replaces white mica growing around the kyanite pseudomorphs. (f) Fine-grained quartz matrix with some biotite and garnet.

Fig. 5. Representative zoning patterns across garnet porphyroblasts (a \& b) and plagioclase porphyroblasts (c \& d) from the hangingwall (a-c) and footwall (d). Garnet profiles are around $2000 \mu \mathrm{m}$ in length and feldspar profiles are around $500 \mu \mathrm{m}$. 
Fig. 6. $P-T$ pseudosections for two metapelitic samples from the hangingwall of the Plattengneiss shear zone. (a) NCKFMASTHO pseudosection for sample T18 with the inferred peak assemblage (bold), $P-T$ conditions (star) and part of the retrograde path, the latter based on the late growth of staurolite in this sample. (b) NCKFMASTHO pseudosection of a metapelitic schist with the inferred peak assemblage (bold), $P-T$ conditions (star) and the inferred high pressure part of the prograde path. Quantitative $P-$ $T$ conditions are constraints using calculated isopleths of garnet, plagioclase and white mica with measured (EPMA) values.

Fig. 7. Results of the av $P$ calculations at four different temperatures.

Fig. 8. Results of the $\Delta P$ calculations at 700 and $750^{\circ} \mathrm{C}$ with (a \& b) $\mathrm{PG} 40$ as the calculation basis and (c \& d) T18 as the basis.

Fig. 9. Summary $P-T$ diagram showing the consistent and overlapping results using both forward and inverse methods on samples T18 and T29. The star marks the best estimate on peak metamorphic conditions.

Fig. 10. Simplified $P-T$ path showing the assumed evolution during the Cretaceous as inferred from $P-T$ data, porphyroblast-inclusion relations and generalized mineral stability fields. 
Fig. 11. Simplified cross-section across the eastern Alps during Eoalpine subduction following fig. 2 of Stüwe \& Schuster (2010). The left-hand diagram shows the envisaged position of the Koralpe (within the circle) in the Koralpe-Wölz complex (KW); 0 O = Ötztal complex. Note that the downward extraction of a sliver of the KW unit implies opposite shear sense indicators in the hanging and footwall of the sliver and volume loss from within. The right-hand diagram shows the likely situation during the onset of rapid exhumation.

\section{TABLE CAPTIONS}

Table 1. List of samples.

Table 2. Representative mineral chemical data (EPMA) from hangingwall rocks.

Table 3: Representative mineral chemical data (EPMA) from footwall rocks.

Table 4. Bulk-rock compositions (mol.\%) used in pseudosection calculations. 
Table 5. The results of the av $P$ calculations for $675,700,725$ and $750^{\circ} \mathrm{C}$.

Table 6 (a) Results of the $\Delta P$ calculations for 700 and $750^{\circ} \mathrm{C}$ relative to sample $\mathrm{PG} 40$.

Table 6 (b) Results of the $\Delta P$ calculations for 700 and $750^{\circ}$ relative to sample $\mathrm{T} 18$. 


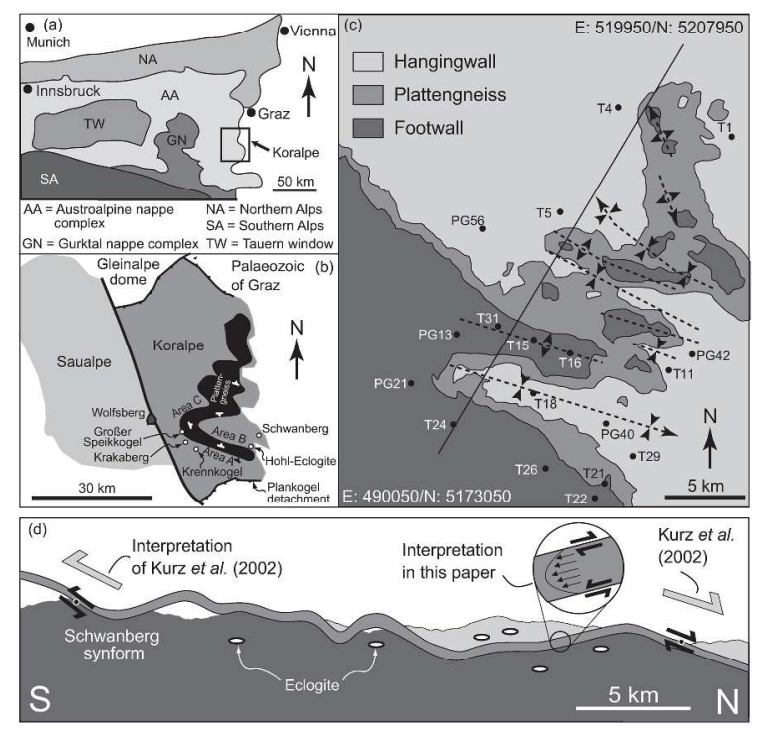

$322 \times 441 \mathrm{~mm}(300 \times 300$ DPI) 


\section{Page 39 of 54}
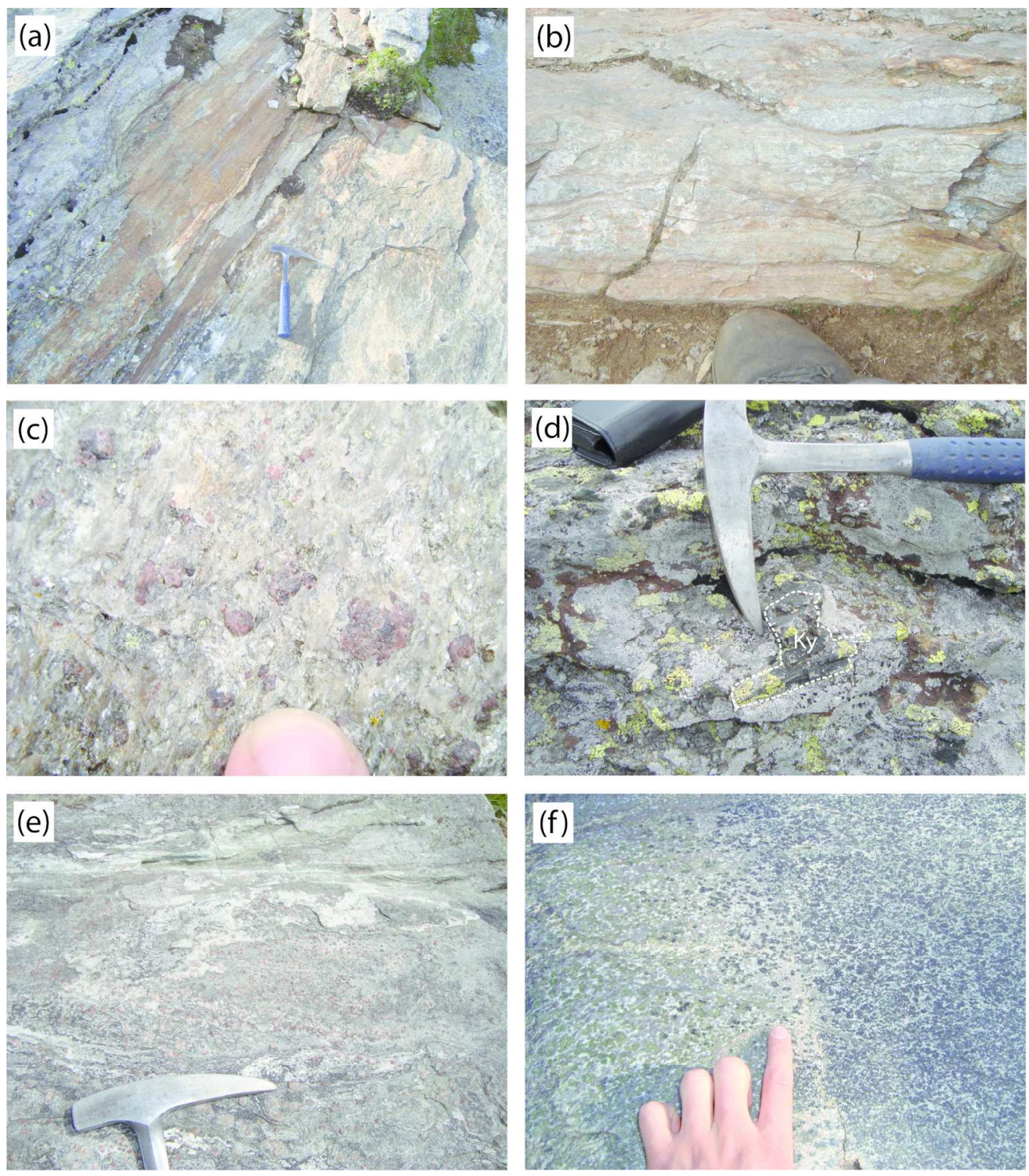

$176 \times 201 \mathrm{~mm}(300 \times 300 \mathrm{DPI})$ 
HANGINGWALL
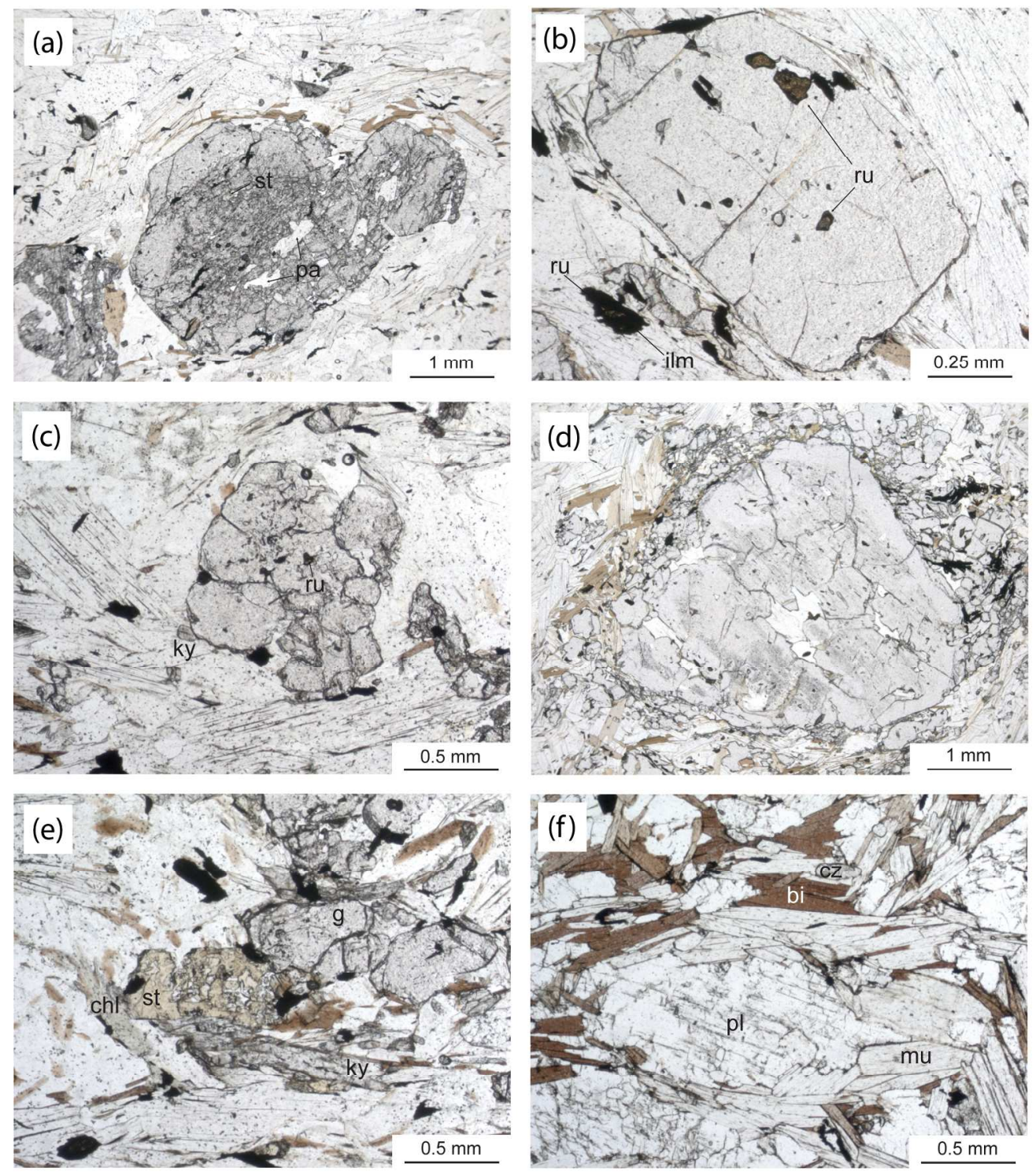

$188 \times 224 \mathrm{~mm}(300 \times 300$ DPI $)$ 


\section{Page 41 of 54}

\section{FOOTWALL}
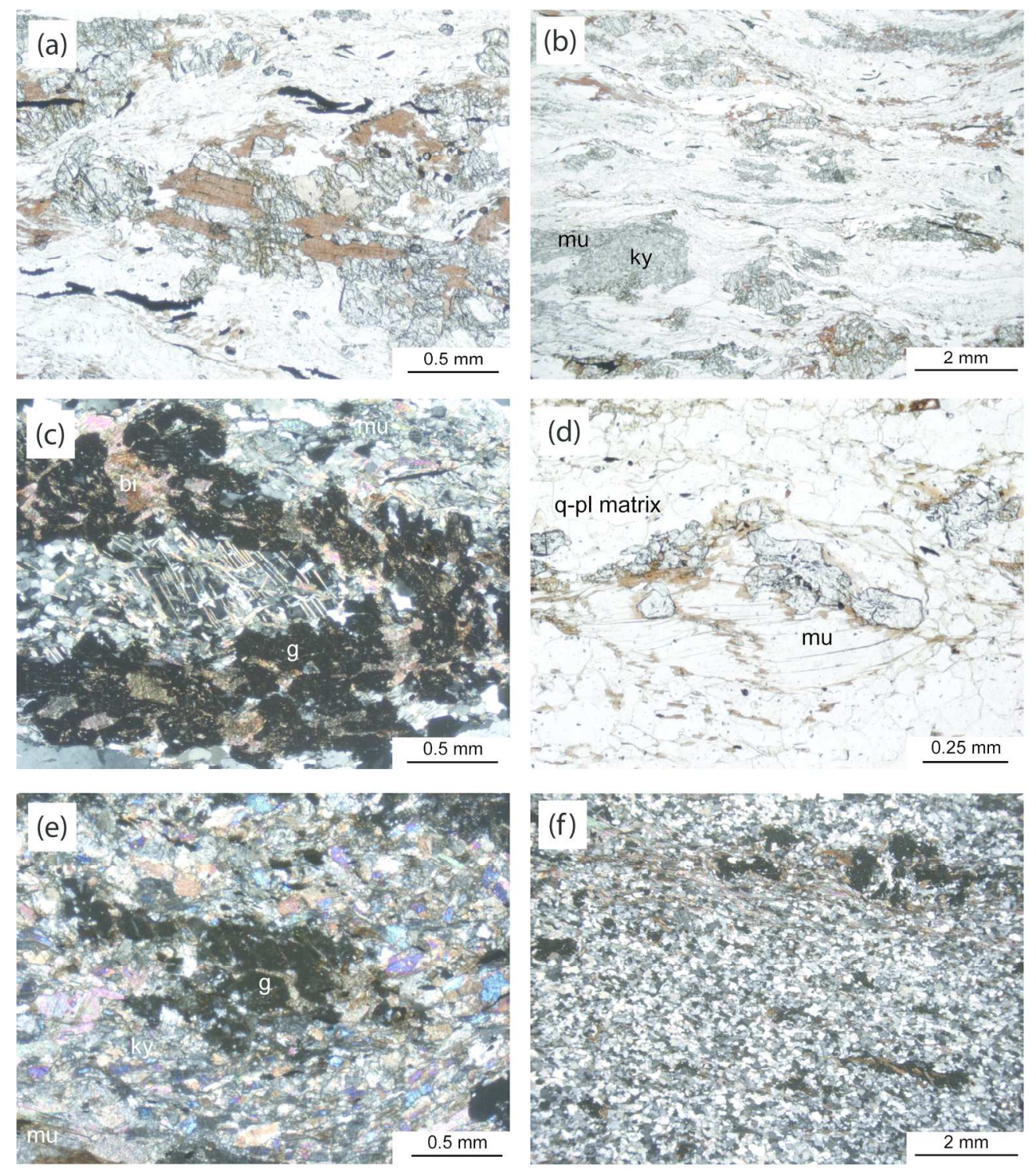

$188 \times 224 \mathrm{~mm}(300 \times 300 \mathrm{DPI})$ 

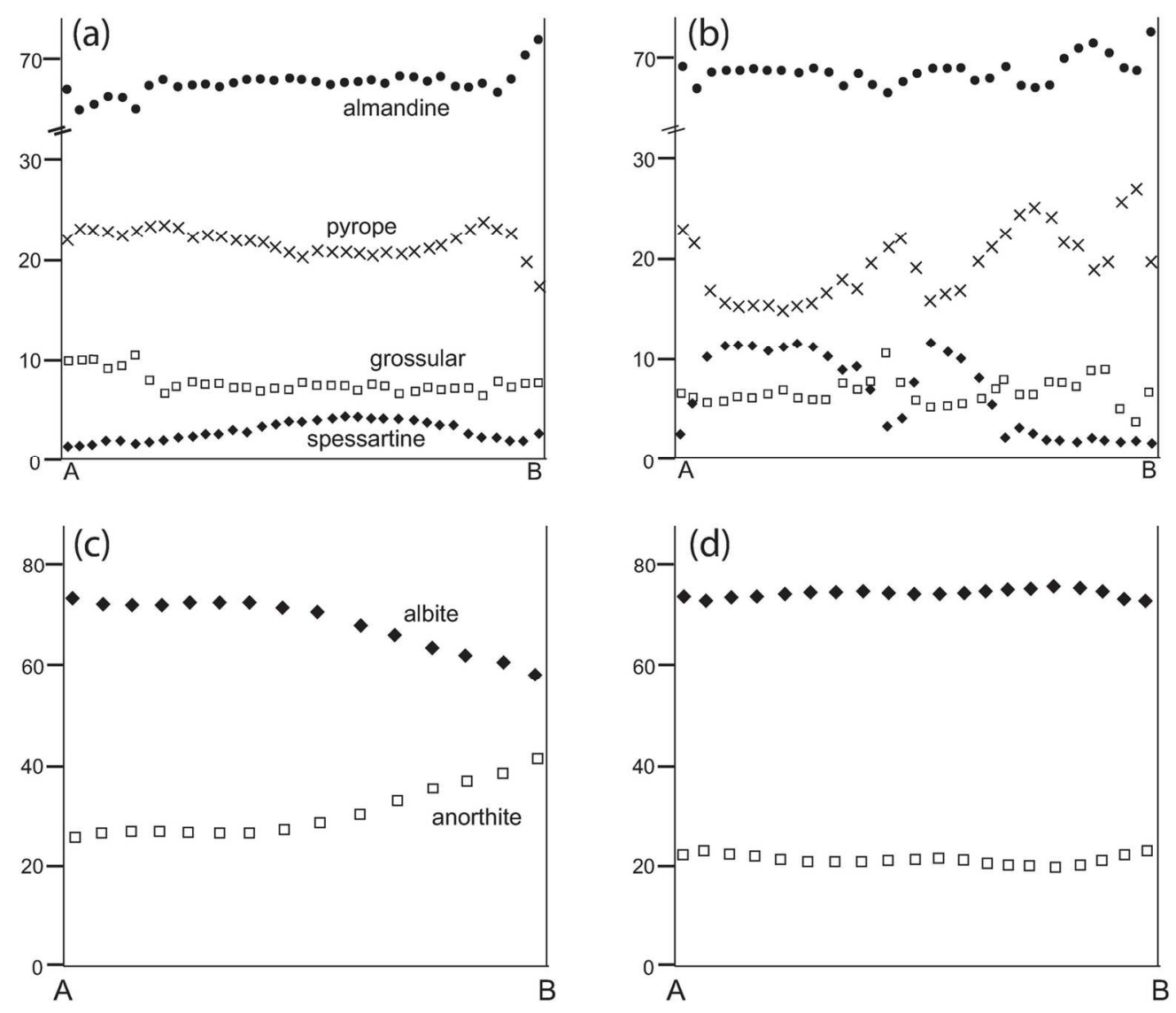

$136 \times 118 \mathrm{~mm}(300 \times 300$ DPI $)$ 


\section{Page 43 of 54}
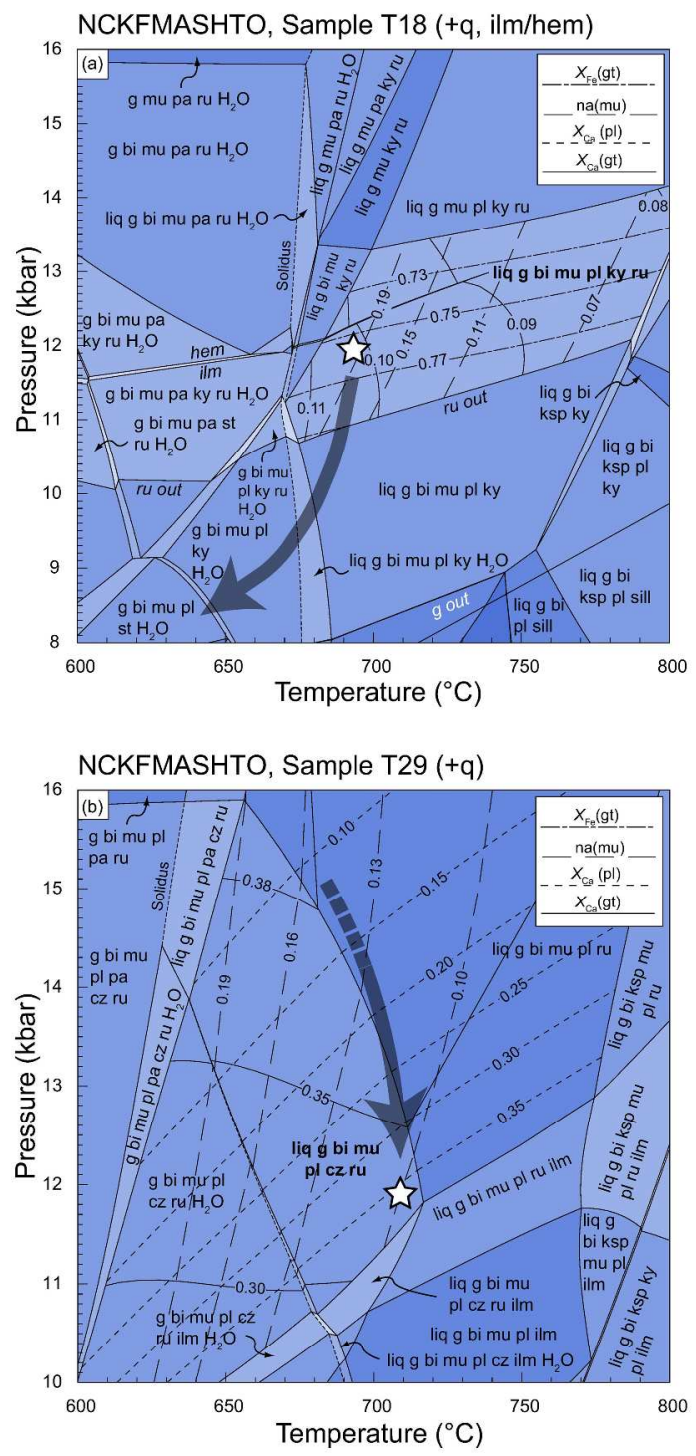

Figure 6

$248 \times 507 \mathrm{~mm}(300 \times 300 \mathrm{DPI})$ 
(a)

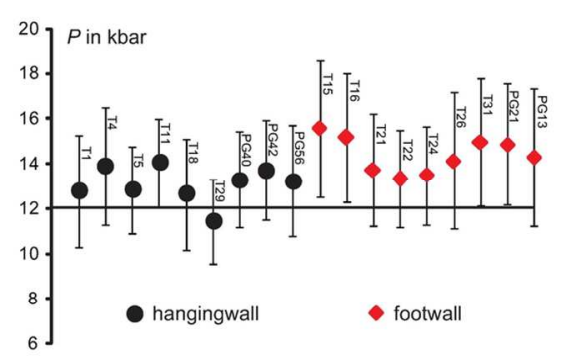

(c)

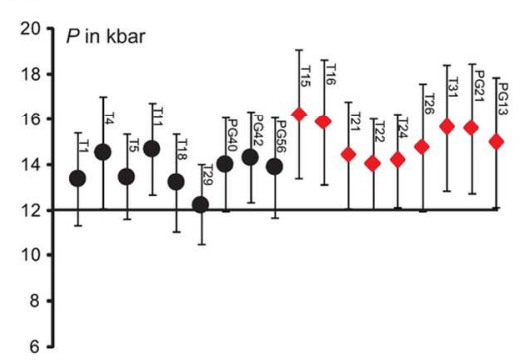

(b)

$700^{\circ} \mathrm{C}$
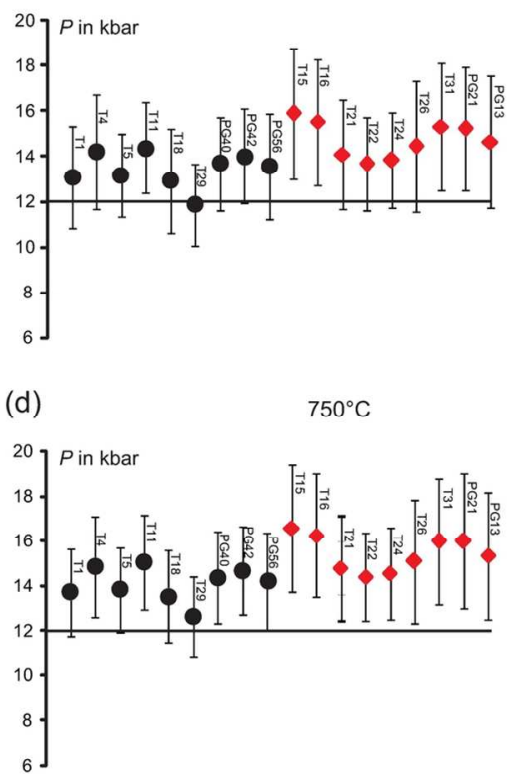

$119 \times 77 \mathrm{~mm}(300 \times 300$ DPI $)$ 


\section{Page 45 of 54}
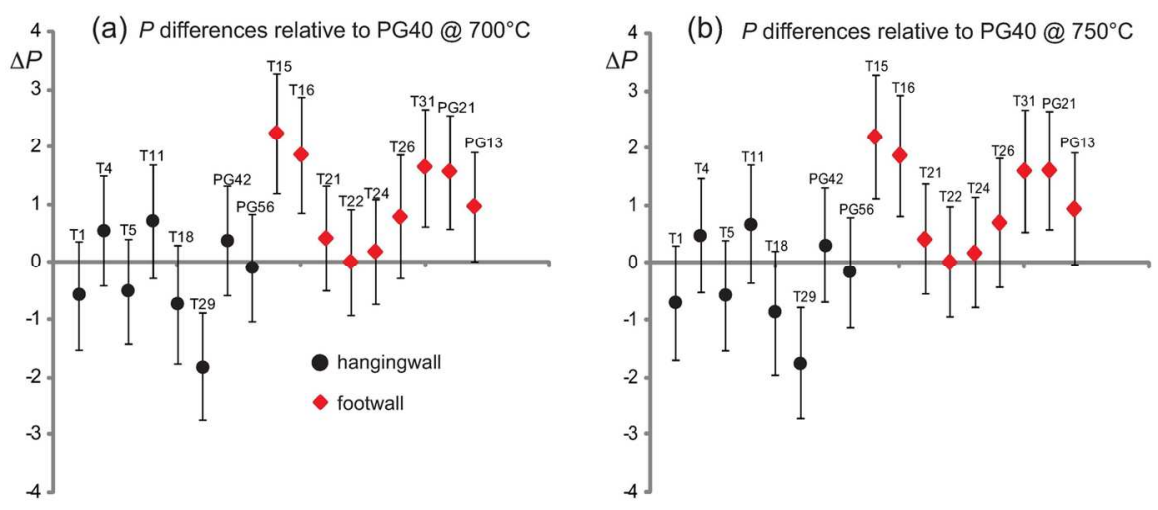

(c) $P$ differences relative to $\mathrm{T} 18 @ 700^{\circ} \mathrm{C}$

(d) $P$ differences relative to T18 @ $750^{\circ} \mathrm{C}$
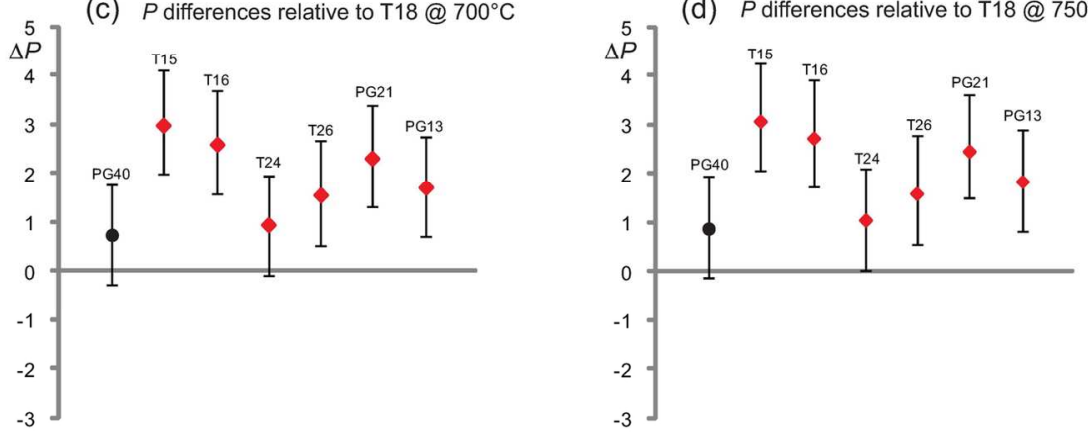

$144 \times 112 \mathrm{~mm}(300 \times 300 \mathrm{DPI})$ 


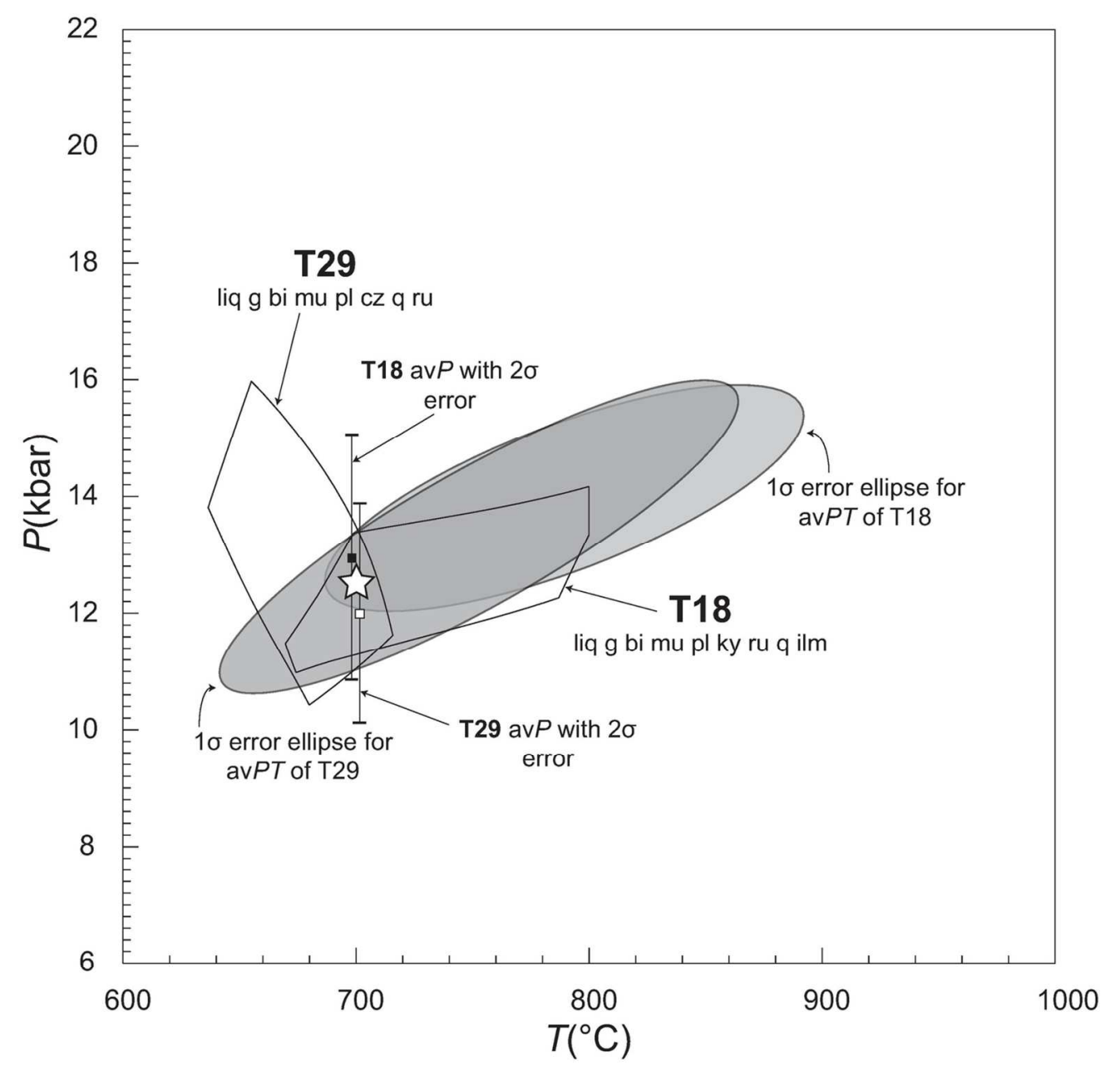

$121 \times 118 \mathrm{~mm}(300 \times 300$ DPI $)$ 


\section{Page 47 of 54}

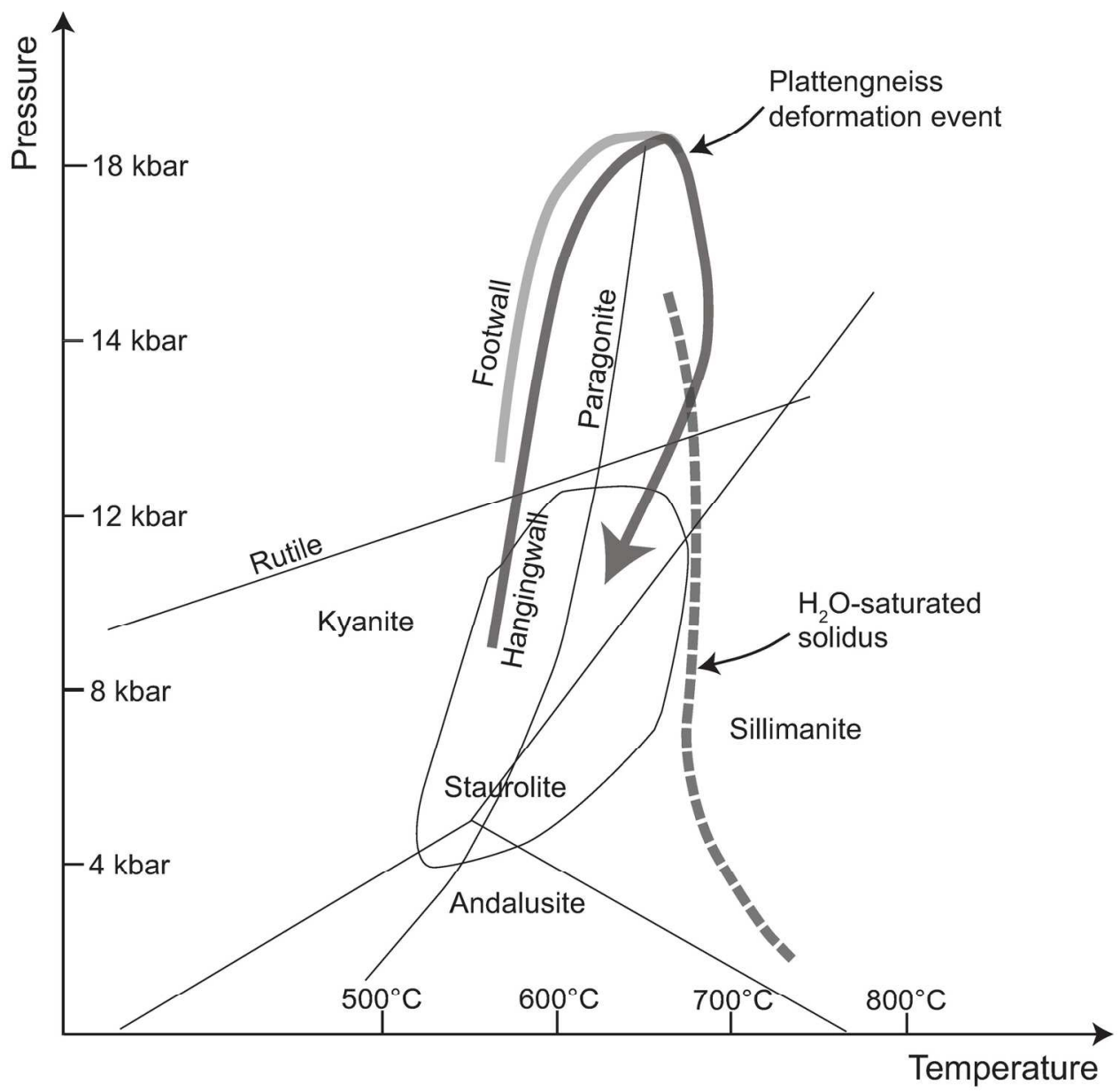

$160 \times 153 \mathrm{~mm}(300 \times 300 \mathrm{DPI})$ 


\section{Page 48 of 54}

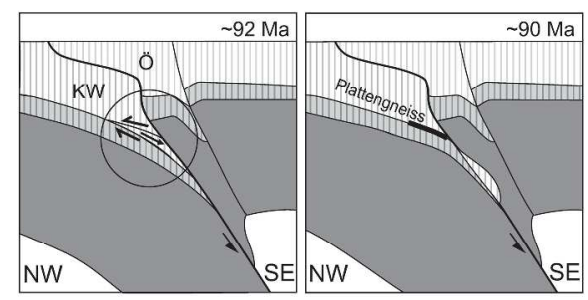

$322 \times 441 \mathrm{~mm}(300 \times 300 \mathrm{DPI})$ 
Table 1

\begin{tabular}{lllllll}
\hline Sample & & Latitude & Longitude & & \\
& Rocktype & North & East & Locality & Reference & Unit \\
\cline { 2 - 7 } T1 & g-bi-micaschist & $46^{\circ} 56.863$ & $15^{\circ} 14.008$ & Gundersdorf & this study & hangingwall \\
T4 & g-bi-micaschist & $46^{\circ} 57.410$ & $15^{\circ} 07.544$ & Aiblwirt & this study & hangingwall \\
T5 & g-bi-st-micaschist & $46^{\circ} 54.666$ & $15^{\circ} 02.455$ & Rehbock-Hütte & this study & hangingwall \\
T11 & paragneiss & $46^{\circ} 49.135$ & $15^{\circ} 10.602$ & Deutschlandsberg & this study & hangingwall \\
T18 & g-bi-st-micaschist & $46^{\circ} 47.302$ & $15^{\circ} 03.844$ & Gregormichel Alm & this study & hangingwall \\
T29 & g-bi-pl-czo-schist & $46^{\circ} 44.749$ & $15^{\circ} 11.318$ & Schwanberg & this study & hangingwall \\
PG40 & micaschist & $46^{\circ} 46.562$ & $15^{\circ} 06.596$ & & Roffeis (2008) & hangingwall \\
PG42 & micaschist & $46^{\circ} 48.620$ & $15^{\circ} 12.143$ & & Roffeis (2008) & hangingwall \\
PG56 & micaschist & $46^{\circ} 53.242$ & $15^{\circ} 00.269$ & & Roffeis (2008) & hangingwall \\
T15 & mylonitic micaschist & $46^{\circ} 49.151$ & $15^{\circ} 04.084$ & Glashütte & this study & footwall \\
T16 & mylonitic micaschist & $46^{\circ} 48.151$ & $15^{\circ} 06.567$ & Lenzbauer Wirt & this study & footwall \\
T21 & mylonitic micaschist & $46^{\circ} 42.953$ & $15^{\circ} 08.215$ & & this study & footwall \\
T22 & mylonitic micaschist & $46^{\circ} 41.752$ & $15^{\circ} 06.850$ & Mauthnerheck & this study & footwall \\
T24 & mylonitic micaschist & $46^{\circ} 45.878$ & $14^{\circ} 58.556$ & Jauksattel & this study & footwall \\
T26 & mylonitic micaschist & $46^{\circ} 44.983$ & $15^{\circ} 03.849$ & Wirtbartl Alm & this study & footwall \\
T31 & metapelitic micaschist & $46^{\circ} 50.124$ & $15^{\circ} 00.867$ & Weinebene & this study & footwall \\
PG21 & mylonitic micaschist & $46^{\circ} 47.272$ & $14^{\circ} 56.688$ & & Roffeis (2008) & footwall \\
PG13 & mylonitic micaschist & $46^{\circ} 49.382$ & $14^{\circ} 59.728$ & & Roffeis (2008) & footwall \\
\hline
\end{tabular}


Table 2

\begin{tabular}{|c|c|c|c|c|c|c|c|c|}
\hline Phase & garnet & & biotite & & muscovit & & plagio & \\
\hline $\begin{array}{l}\text { Sample } \\
\text { Position }\end{array}$ & $\begin{array}{l}\text { T18 } \\
\text { small gt }\end{array}$ & $\begin{array}{l}\text { PG56 } \\
\text { core } \\
\end{array}$ & $\begin{array}{l}\mathrm{T} 4 \\
\text { matrix }\end{array}$ & $\begin{array}{l}\text { T29 } \\
\text { matrix }\end{array}$ & $\begin{array}{l}\text { T4 } \\
\text { pa in gt }\end{array}$ & $\begin{array}{l}\mathrm{T} 1 \\
\text { matrix }\end{array}$ & $\begin{array}{l}\text { T29 } \\
\text { core }\end{array}$ & $\begin{array}{l}\text { T4 } \\
\text { matrix }\end{array}$ \\
\hline $\mathrm{SiO}_{2}$ & 38.52 & 38.20 & 37.69 & 36.84 & 45.58 & 46.96 & 63.47 & 66.18 \\
\hline $\mathrm{TiO}_{2}$ & 0.00 & 0.03 & 1.54 & 2.66 & 0.17 & 0.68 & 0.03 & 0.02 \\
\hline $\mathrm{Al}_{2} \mathrm{O}_{3}$ & 21.80 & 21.29 & 18.36 & 17.78 & 39.72 & 32.40 & 22.24 & 20.82 \\
\hline $\mathrm{Cr}_{2} \mathrm{O}_{3}$ & 0.03 & 0.01 & 0.10 & 0.07 & 0.05 & 0.02 & 0.03 & 0.00 \\
\hline $\mathrm{FeO}$ & 30.36 & 30.28 & 16.01 & 18.94 & 0.82 & 1.37 & 0.03 & 0.03 \\
\hline $\mathrm{MnO}$ & 0.74 & 5.57 & 0.05 & 0.17 & 0.04 & 0.01 & 0.00 & 0.03 \\
\hline $\mathrm{MgO}$ & 6.05 & 3.80 & 12.85 & 10.30 & 0.07 & 1.49 & 0.02 & 0.00 \\
\hline $\mathrm{CaO}$ & 3.35 & 1.89 & 0.00 & 0.00 & 0.78 & 0.00 & 3.95 & 1.90 \\
\hline $\mathrm{Na}_{2} \mathrm{O}$ & 0.01 & 0.02 & 0.24 & 0.17 & 6.73 & 1.18 & 9.08 & 10.71 \\
\hline $\mathrm{K}_{2} \mathrm{O}$ & 0.00 & 0.00 & 8.46 & 9.47 & 0.91 & 9.32 & 0.17 & 0.06 \\
\hline Total & 100.86 & 101.09 & 95.30 & 96.40 & 94.87 & 93.43 & 99.02 & 99.75 \\
\hline Oxygens & 12 & 12 & 11 & 11 & 11 & 11 & 8 & 8 \\
\hline $\mathrm{Si}$ & 3.00 & 3.01 & 2.79 & 2.76 & 2.94 & 3.17 & 2.83 & 2.91 \\
\hline $\mathrm{Ti}$ & 0.00 & 0.00 & 0.09 & 0.15 & 0.01 & 0.03 & 0.00 & 0.00 \\
\hline $\mathrm{Al}$ & 2.00 & 1.98 & 1.60 & 1.57 & 3.02 & 2.58 & 1.17 & 1.08 \\
\hline $\mathrm{Cr}$ & 0.00 & 0.00 & 0.00 & 0.00 & 0.00 & 0.00 & 0.00 & 0.00 \\
\hline $\mathrm{Fe}^{2+}$ & 1.98 & 2.00 & 0.99 & 1.19 & 0.04 & 0.08 & 0.00 & 0.00 \\
\hline $\mathrm{Mn}$ & 0.05 & 0.37 & 0.00 & 0.01 & 0.00 & 0.00 & 0.00 & 0.00 \\
\hline $\mathrm{Mg}$ & 0.70 & 0.45 & 1.41 & 1.15 & 0.01 & 0.15 & 0.00 & 0.00 \\
\hline $\mathrm{Ca}$ & 0.28 & 0.16 & 0.00 & 0.00 & 0.05 & 0.00 & 0.19 & 0.09 \\
\hline $\mathrm{Na}$ & 0.00 & 0.00 & 0.03 & 0.02 & 0.84 & 0.15 & 0.78 & 0.91 \\
\hline $\mathrm{K}$ & 0.00 & 0.00 & 0.79 & 0.91 & 0.08 & 0.80 & 0.01 & 0.00 \\
\hline Total & 8.01 & 7.97 & 7.70 & 7.76 & 6.99 & 6.96 & 4.98 & 4.99 \\
\hline
\end{tabular}


Table 3

\begin{tabular}{|c|c|c|c|c|c|c|c|c|}
\hline Phase & garnet & & biotite & & muscovit & & plagioc & \\
\hline $\begin{array}{l}\text { Sample } \\
\text { Position }\end{array}$ & $\begin{array}{l}\mathrm{T} 22 \\
\text { core } \\
\end{array}$ & $\begin{array}{l}\text { T16 } \\
\text { small gt }\end{array}$ & $\begin{array}{l}\text { T22 } \\
\text { incl in gt }\end{array}$ & $\begin{array}{l}\text { T15 } \\
\text { matrix }\end{array}$ & $\begin{array}{l}\text { T11 } \\
\text { mu in pl }\end{array}$ & $\begin{array}{l}\mathrm{T} 24 \\
\text { around ky }\end{array}$ & $\begin{array}{l}\mathrm{T} 15 \\
\text { matrix }\end{array}$ & $\begin{array}{l}\text { T24 } \\
\text { matrix }\end{array}$ \\
\hline $\mathrm{SiO}_{2}$ & 37.52 & 38.75 & 35.91 & 37.74 & 47.42 & 47.48 & 66.39 & 66.24 \\
\hline $\mathrm{TiO}_{2}$ & 0.00 & 0.20 & 4.04 & 2.97 & 0.50 & 0.23 & 0.00 & 0.00 \\
\hline $\mathrm{Al}_{2} \mathrm{O}_{3}$ & 21.14 & 21.62 & 18.07 & 18.70 & 31.42 & 32.82 & 20.28 & 20.16 \\
\hline $\mathrm{Cr}_{2} \mathrm{O}_{3}$ & 0.05 & 0.03 & 0.02 & 0.05 & 0.03 & 0.02 & 0.05 & 0.04 \\
\hline $\mathrm{FeO}$ & 32.53 & 30.00 & 17.95 & 12.89 & 1.30 & 1.21 & 0.07 & 0.05 \\
\hline $\mathrm{MnO}$ & 5.28 & 0.88 & 0.10 & 0.00 & 0.05 & 0.00 & 0.02 & 0.00 \\
\hline $\mathrm{MgO}$ & 2.72 & 4.37 & 9.47 & 13.39 & 1.78 & 1.72 & 0.01 & 0.01 \\
\hline $\mathrm{CaO}$ & 1.82 & 5.53 & 0.00 & 0.00 & 0.17 & 0.00 & 1.43 & 1.69 \\
\hline $\mathrm{Na}_{2} \mathrm{O}$ & 0.03 & 0.08 & 0.13 & 0.19 & 0.80 & 0.19 & 11.11 & 10.68 \\
\hline $\mathrm{K}_{2} \mathrm{O}$ & 0.00 & 0.00 & 9.43 & 9.02 & 10.01 & 10.85 & 0.12 & 0.21 \\
\hline Total & 101.09 & 101.46 & 95.12 & 94.95 & 93.48 & 94.52 & 99.48 & 99.08 \\
\hline Oxygens & 12 & 12 & 11 & 11 & 11 & 11 & 8 & 8 \\
\hline $\mathrm{Si}$ & 3.00 & 3.01 & 2.72 & 2.77 & 3.21 & 3.18 & 2.93 & 2.94 \\
\hline $\mathrm{Ti}$ & 0.00 & 0.01 & 0.23 & 0.16 & 0.03 & 0.01 & 0.00 & 0.00 \\
\hline $\mathrm{Al}$ & 1.99 & 1.98 & 1.61 & 1.62 & 2.51 & 2.59 & 1.06 & 1.05 \\
\hline $\mathrm{Cr}$ & 0.00 & 0.00 & 0.00 & 0.00 & 0.00 & 0.00 & 0.00 & 0.00 \\
\hline $\mathrm{Fe}^{2+}$ & 2.17 & 1.95 & 1.14 & 0.79 & 0.08 & 0.07 & 0.00 & 0.00 \\
\hline $\mathrm{Mn}$ & 0.36 & 0.06 & 0.01 & 0.00 & 0.00 & 0.00 & 0.00 & 0.00 \\
\hline $\mathrm{Mg}$ & 0.32 & 0.51 & 1.07 & 1.47 & 0.18 & 0.17 & 0.00 & 0.00 \\
\hline $\mathrm{Ca}$ & 0.16 & 0.46 & 0.00 & 0.00 & 0.01 & 0.00 & 0.07 & 0.08 \\
\hline $\mathrm{Na}$ & 0.00 & 0.01 & 0.02 & 0.03 & 0.11 & 0.02 & 0.95 & 0.92 \\
\hline $\mathrm{K}$ & 0.00 & 0.00 & 0.91 & 0.85 & 0.87 & 0.93 & 0.01 & 0.01 \\
\hline Total & 8.00 & 7.99 & 7.71 & 7.69 & 7.00 & 6.97 & 5.02 & 5.00 \\
\hline
\end{tabular}




\section{Table 4}

\begin{tabular}{llllllllllll}
\hline Sample & $\mathrm{Na}_{2} \mathrm{O}$ & $\mathrm{CaO}$ & $\mathrm{K}_{2} \mathrm{O}$ & $\mathrm{FeO}$ & $\mathrm{MgO}$ & $\mathrm{Al}_{2} \mathrm{O}_{3}$ & $\mathrm{SiO}_{2}$ & $\mathrm{H}_{2} \mathrm{O}$ & $\mathrm{TiO}_{2}$ & $\mathrm{O}\left(=\mathrm{Fe}_{2} \mathrm{O}_{3}\right)$ & Total \\
$\mathrm{T} 18$ & 1.14 & 0.92 & 2.53 & 6.72 & 2.86 & 13.02 & 62.41 & 9.34 & 0.72 & 0.16 & 99.82 \\
$\mathrm{~T} 29$ & 1.61 & 4.12 & 2.06 & 5.95 & 2.96 & 10.43 & 66.20 & 5.28 & 0.54 & 0.14 & 99.29 \\
\hline
\end{tabular}


Table 5

\begin{tabular}{llllllllllllll}
\hline Temperature & 675 & & \multicolumn{1}{c}{700} & \multicolumn{1}{c}{725} & \multicolumn{3}{c}{750} \\
\cline { 2 - 12 } Sample & avP & $2 \sigma$ & $\sigma$-fit & av $P$ & $2 \sigma$ & $\sigma$-fit & av $P$ & $2 \sigma$ & $\sigma$-fit & av $P$ & $2 \sigma$ & $\sigma$-fit \\
\hline T1 & 12.76 & 2.50 & 1.39 & 13.08 & 2.26 & 1.23 & 13.38 & 2.04 & 1.08 & 13.69 & 1.94 & 0.95 \\
T4 & 13.87 & 2.60 & 1.39 & 14.21 & 2.52 & 1.31 & 14.54 & 2.48 & 1.25 & 14.87 & 2.26 & 1.22 \\
T5 & 12.82 & 1.92 & 1.09 & 13.16 & 1.82 & 1.00 & 13.50 & 1.86 & 0.94 & 13.82 & 1.90 & 0.91 \\
T11 & 14.03 & 1.94 & 0.90 & 14.38 & 2.00 & 0.88 & 14.72 & 2.04 & 0.89 & 15.06 & 2.10 & 0.92 \\
T18 & 12.63 & 2.46 & 1.28 & 12.93 & 2.30 & 1.17 & 13.22 & 2.16 & 1.07 & 13.52 & 2.06 & 0.99 \\
T29 & 11.44 & 1.88 & 1.44 & 11.85 & 1.82 & 1.36 & 12.23 & 1.78 & 1.29 & 12.63 & 1.78 & 1.26 \\
PG40 & 13.29 & 2.12 & 1.28 & 13.67 & 2.06 & 1.21 & 14.03 & 2.04 & 1.17 & 14.39 & 2.06 & 1.15 \\
PG42 & 13.71 & 2.22 & 1.21 & 14.03 & 2.06 & 1.10 & 14.36 & 1.98 & 1.02 & 14.69 & 1.98 & 0.98 \\
PG56 & 13.22 & 2.46 & 1.35 & 13.56 & 2.32 & 1.25 & 13.89 & 2.22 & 1.16 & 14.22 & 2.16 & 1.10 \\
T15 & 15.56 & 3.02 & 1.54 & 15.90 & 2.90 & 1.45 & 16.25 & 2.86 & 1.38 & 16.59 & 2.84 & 1.34 \\
T16 & 15.15 & 2.86 & 1.48 & 15.52 & 2.78 & 1.41 & 15.89 & 2.74 & 1.35 & 16.26 & 2.74 & 1.32 \\
T21 & 13.72 & 2.50 & 1.42 & 14.08 & 2.40 & 1.34 & 14.44 & 2.36 & 1.28 & 14.80 & 2.36 & 1.24 \\
T22 & 13.31 & 2.16 & 1.28 & 13.67 & 2.06 & 1.19 & 14.04 & 2.00 & 1.12 & 14.40 & 1.98 & 1.08 \\
T24 & 13.49 & 2.18 & 1.23 & 13.85 & 2.10 & 1.16 & 14.21 & 2.06 & 1.11 & 14.56 & 2.06 & 1.08 \\
T26 & 14.13 & 3.00 & 1.49 & 14.45 & 2.88 & 1.40 & 14.77 & 2.80 & 1.32 & 15.09 & 2.74 & 1.27 \\
T31 & 14.94 & 2.84 & 1.49 & 15.31 & 2.80 & 1.43 & 15.65 & 2.78 & 1.38 & 15.99 & 2.80 & 1.36 \\
PG21 & 14.84 & 2.68 & 1.42 & 15.23 & 2.74 & 1.42 & 15.61 & 2.86 & 1.44 & 16.00 & 3.00 & 1.47 \\
PG13 & 14.28 & 3.02 & 1.64 & 14.63 & 2.90 & 1.54 & 14.98 & 2.86 & 1.48 & 15.33 & 2.84 & 1.43 \\
\hline
\end{tabular}




\section{Table 6a}

\begin{tabular}{lllll}
\hline Temperature & $700 ; \mathrm{C}$ & \multicolumn{3}{l}{$750 \mathrm{i} \mathrm{C}$} \\
\cline { 2 - 5 } Sample & $\Delta P$ & $2 \sigma$ & $\Delta P$ & $2 \sigma$ \\
\cline { 2 - 5 } T1 & -0.59 & 0.95 & -0.70 & 0.99 \\
T4 & 0.54 & 0.95 & 0.48 & 0.99 \\
T5 & -0.51 & 0.92 & -0.57 & 0.96 \\
T11 & 0.71 & 0.99 & 0.67 & 1.03 \\
T18 & -0.74 & 1.03 & -0.87 & 1.08 \\
T29 & -1.82 & 0.93 & -1.76 & 0.98 \\
PG40 & 0.00 & 0.92 & 0.00 & 0.96 \\
PG42 & 0.36 & 0.96 & 0.30 & 1.00 \\
PG56 & -0.11 & 0.93 & -0.17 & 0.97 \\
T15 & 2.23 & 1.04 & 2.20 & 1.08 \\
T16 & 1.85 & 1.01 & 1.87 & 1.06 \\
T21 & 0.41 & 0.92 & 0.41 & 0.96 \\
T22 & 0.00 & 0.92 & 0.01 & 0.96 \\
T24 & 0.18 & 0.92 & 0.17 & 0.96 \\
T26 & 0.78 & 1.07 & 0.70 & 1.12 \\
T31 & 1.64 & 1.02 & 1.60 & 1.06 \\
PG21 & 1.56 & 0.98 & 1.61 & 1.03 \\
PG13 & 0.96 & 0.94 & 0.94 & 0.98 \\
\hline
\end{tabular}

Table 6b

\begin{tabular}{lllll}
\hline Temperature & $700 ; \mathrm{C}$ & \multicolumn{3}{l}{$750 ; \mathrm{C}$} \\
\cline { 2 - 5 } Samples & $\Delta P$ & $2 \sigma$ & $\Delta P$ & $2 \sigma$ \\
\cline { 2 - 5 } PG40 & 0.74 & 1.03 & 0.87 & 1.08 \\
T15 & 2.97 & 1.13 & 3.07 & 1.19 \\
T16 & 2.59 & 1.11 & 2.74 & 1.17 \\
T24 & 0.92 & 1.03 & 1.04 & 1.08 \\
T26 & 1.52 & 1.17 & 1.57 & 1.23 \\
PG21 & 2.30 & 1.08 & 2.48 & 1.14 \\
PG13 & 1.70 & 1.04 & 1.81 & 1.10 \\
\hline
\end{tabular}

